\title{
Spatial and temporal variability of food web structure during the spring bloom in the Skagerrak
}

\author{
Marie Maar ${ }^{1,2, *}$, Torkel Gissel Nielsen ${ }^{1}$, Katherine Richardson ${ }^{2}$, Urania Christaki ${ }^{3}$, \\ Ole Schou Hansen ${ }^{1}$, Sultana Zervoudaki ${ }^{3}$, Epaminondas D. Christou ${ }^{3}$
}

\author{
${ }^{1}$ Department of Marine Ecology, National Environmental Research Institute, PO Box 358, Frederiksborgvej 399, \\ 4000 Roskilde, Denmark \\ ${ }^{2}$ Department of Marine Ecology, University of Aarhus, Finlandsgade 14, 8200 Århus, Denmark \\ ${ }^{3}$ National Centre for Marine Research, 16604 Hellenikon, Athens, Greece
}

\begin{abstract}
During the intense spring diatom bloom, the spatial $(\mathrm{km})$ and temporal $(\mathrm{h})$ variability of the pelagic food web structure was investigated in the Skagerrak. Three surface water masses could be identified in the study area based on their temperature, salinity and biogeochemical characteristics. When the measured biological parameters were separated into water masses instead of stations, food web variability decreased by up to $41 \%$. However, specific egg production rate by Acartia clausi and Oithona similis did not correlate with water masses and was probably influenced by other factors, e.g. small-scale turbulence. Bacterial production and Calanus-grazing followed a diurnal cycle with increased activity during the night. The grazing impact by the copepod community was assessed by the egg production and the gut fluorescence method. Despite the Calanus population, the copepod community only grazed $<3 \%$ of daily primary production. The protozooplankton, however, ingested 2 to 4 times more of primary production than the copepods. Overall, the zooplankton community only grazed $17 \%$ of daily primary production, and consequently the majority of the spring bloom will leave the euphotic zone ungrazed as a potential food source for the benthos.
\end{abstract}

KEY WORDS: Spring bloom · Diurnal and spatial variability $\cdot$ Pelagic food web $\cdot$ Protozoans $\cdot$ Copepods

Resale or republication not permitted without written consent of the publisher

\section{INTRODUCTION}

In temperate waters, the combination of nutrients delivered to surface waters via winter mixing, increased irradiance, and stratification of the water column triggers a spring bloom, usually dominated by diatoms. The fate of the spring bloom depends on the nutrient supply and the structure of the community of potential grazers present and their ability to utilize the bloom species as food sources (Kiørboe 1993, Wassmann 1998). Historically, it has been assumed that the most important grazers of the spring bloom are mesozooplankton. Accordingly, most effort has been directed towards quantifying the copepod grazing pressure

*E-mail: mam@dmu.dk in spring bloom situations, in order to understand the fate of the blooms (e.g. Steele 1974, Smith \& Lane 1988, Tiselius 1988).

In temperate shallow coastal waters, several studies have, however, shown that copepod biomass is low in early spring. This results in a considerable mismatch between the growth of phytoplankton and grazing pressure from copepods (Deason 1980, Tiselius 1988, Kiørboe \& Nielsen 1994). Protozooplankton (ciliates and dinoflagellates), on the other hand, peak coincidently with the spring bloom, and these organisms can constitute a substantial proportion of the zooplankton biomass (Smetacek 1981, Hansen 1991, Nielsen \& Kiørboe 1994).

In contrast, in temperate deeper waters (>100 m) with overwintering copepod populations, little attention has been directed towards the study of protozoo- 
plankton and their role in the fate of the spring bloom. Here, it is assumed that the large copepods (i.e. Calanus spp., Metridia spp.) migrate to the surface prior to the spring bloom, thus establishing a substantial community of mesozooplankton coincident with the spring bloom. This reduces the time lag between phytoplankton growth and copepod grazing observed in more shallow coastal waters (Joiris et al. 1982, Tiselius 1988). Consequently, the classical food chain has been assumed to dominate in deeper waters, and the potential role of the microbial food web has often not been addressed.

A recent study in Norwegian fjords, however, showed that the grazing impact of protozoans was 12 to $26 \%$ of the primary production during a spring bloom comprised of diatoms and Phaeocystis pouchetii (Archer et al. 2000). In Disko Bay (Greenland), and in Puget Sound and the Gulf of Alaska (Washington), the grazing impact on phytoplankton by protozoans was comparable to, or higher than, that of copepods (Nielsen \& Hansen 1995, Strom et al. 2001). There is therefore increasing evidence that, even in systems with overwintering copepods, quantification of the fate of the spring bloom requires examination of the activities of the zooplankton community as a whole and not only the copepods.

In the Skagerrak, there is an overwintering population of Calanus finmarchicus, but, until now, no studies

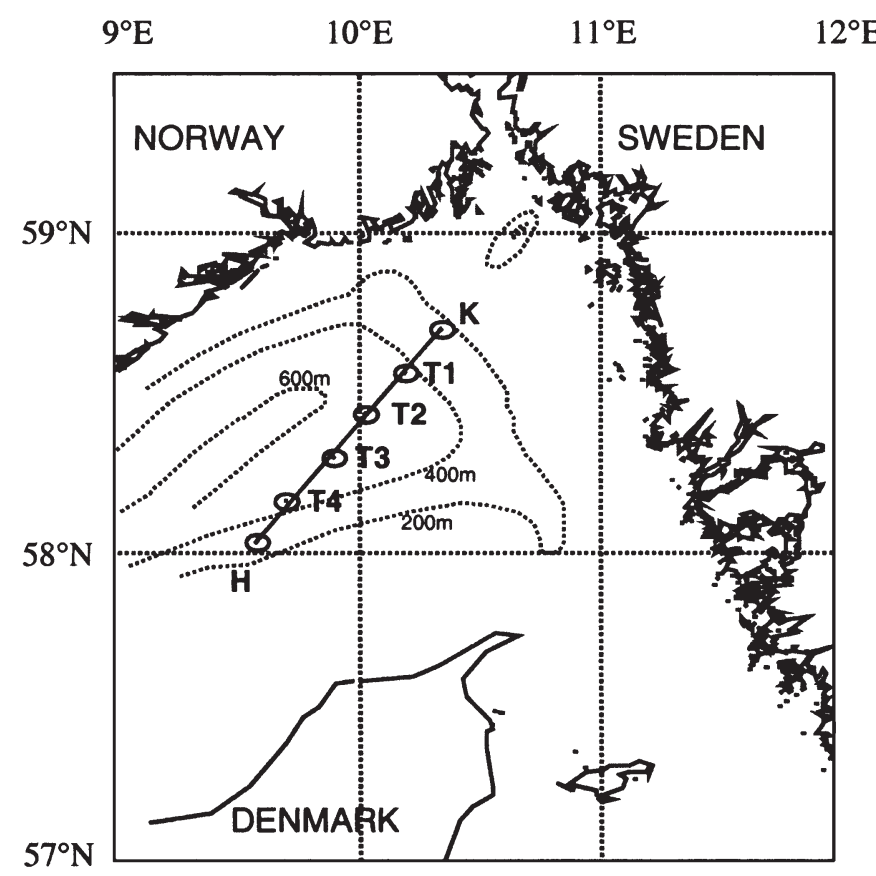

Fig. 1. Map of the Skagerrak between Norway and Denmark with the sampling stations. The 2 intensive stations Koster (Stn K) and Hirtshals (Stn $\mathrm{H}$ ) had the positions $58^{\circ} 42^{\prime} 0^{\prime \prime} \mathrm{N}$, $10^{\circ} 22^{\prime} 0^{\prime \prime} \mathrm{E}$ and $58^{\circ} 02^{\prime} 0^{\prime \prime} \mathrm{N}, 09^{\circ} 36^{\prime} 0^{\prime \prime} \mathrm{E}$, respectively have directly measured the coupling between primary production, protozooplankton and mesozoopankton grazers during the spring bloom. The purpose of this study was therefore to quantify the total impact of grazing on the spring bloom in the Skagerrak by describing the distribution and activity of various components of the planktonic food web in surface waters.

The Skagerrak is located between Denmark and Norway and constitutes the transition zone between the North Sea and the Kattegat/Baltic Sea. The surface water masses form a large-scale cyclonic circulation and consist of the incoming Jutland Current along the coast of Denmark, which together with the Baltic Current forms the outgoing Norwegian Coastal Current (Svansson 1975). The high saline bottom layer consists of Atlantic Sea water and is to some extent mixed with surface waters. The remaining water body, the Skagerrak water, is a mixture of the different water masses entering the area. The food web structure in the Skagerrak is strongly related to the hydrodynamics of the region on the spatial, seasonal and diurnal scales, and a high variability of the food web structure is observed within the area (Kiørboe et al. 1990, Rosenberg et al. 1990, Tiselius et al. 1991, Heilmann et al. 1994, Talpsepp et al. 1999). This is also a particularly interesting ecosystem to study as the area receives coastal waters from a large and heavily populated catchment area. Thus, the waters entering the Skagerrak are, potentially, influenced by the introduction of nutrients and organic compounds originating from human activities.

Understanding the variability in food web structure in a hydrographically dynamic region such as the Skagerrak is also important in order to quantify changes in ecological processes over time as a function of either natural or anthropogenically mediated environmental change. To do so, knowledge of the natural variability associated with the ecological process in question is essential. Thus, in addition to contributing new knowledge with respect to food web structure in the Skagerrak, this study has wider implications regarding future quantification of change within this system.

\section{MATERIALS AND METHODS}

Study site. The investigation was conducted onboard the RV 'Dana' (Danish Fisheries Research Institute, DIFRES) from 20 to 28 March 1999. Sampling was conducted along a transect comprised of 6 stations crossing the Skagerrak roughly parallel to the Danish coast (Fig. 1). Two intensively sampled stations, Koster (Stn K) and Hirtshals (Stn H), were located at the NE and SW ends of the transect, respectively. Firstly, we sampled Stn K on 20 to 22 March for 48 h at 6 h inter- 
vals starting at 06:00 $\mathrm{h}$. We then sampled along the transect running between Stns K and H on 24 March, which included the stations, T1 $(06: 00 \mathrm{~h}), \mathrm{T} 2(09: 00 \mathrm{~h})$, T3 (13:00 h) and T4 (15:00 h). Finally, we sampled at Stn $\mathrm{H}$ on 25 to 27 March for $48 \mathrm{~h}$ at $6 \mathrm{~h}$ intervals starting at 06:00 $\mathrm{h}$.

Hydrography. Profiles of temperature, salinity and fluorescence were measured continuously from surface to 100 to $300 \mathrm{~m}$ using a Seabird CTD System (911 plus) equipped with a Wetstar fluorometer. In situ fluorescence measurements were calibrated against $\mathrm{chl}$ a concentrations from the estimated linear calibration equation $\left(n=25, R^{2}=0.82, p<0.01\right)$. Based on the CTD and fluorescence profiles, 5 depths were selected for further chemical and biological measurements. Water samples were collected using 51 Niskin bottles.

Nutrients. Water samples for measurements of nutrient concentrations $\left(\mathrm{NO}_{2}{ }^{-}, \mathrm{NO}_{3}{ }^{-}, \mathrm{PO}_{4}{ }^{-}\right.$and $\left.\mathrm{SiO}_{4}{ }^{3-}\right)$ were preserved by the immediate addition of 5 drops of chloroform to $25 \mathrm{ml}^{-1}$ samples and kept cold in the dark until determination on shore. Nutrient concentrations were determined at the DIFRES using methods described by Grasshoff (1976). The N/P ratio was determined as $\left(\mathrm{NO}_{3}+\mathrm{NO}_{2}\right) / \mathrm{PO}_{4}$.

Phytoplankton. Chlorophyll a ( $\mathrm{chl}$ a) and phaeopigment concentrations were estimated for calibration of the Wetstar fluorometer: 2 to $4 \mathrm{l}$ of seawater were filtered onto GF/F filters, extracted in $5 \mathrm{ml} \mathrm{90 \%} \mathrm{acetone}$ for 6 to $24 \mathrm{~h}$ and measured before and after addition of acid on a spectrophotometer following the protocol described by Lorenzen (Strickland \& Parsons 1972). Absorbance was also measured at $480 \mathrm{~nm}$ in order to obtain an approximate carotenoid/chlorophyll (480/ 665) ratio for each sample. This ratio gives an indication of the nutrient status of the phytoplankton in a given sample (Heath et al. 1990). For estimation of fractionated chl $a, 100$ to $200 \mathrm{ml}$ of seawater were filtered onto GF/F, 10, 45 and $200 \mu \mathrm{m}$ filters, extracted in $5 \mathrm{ml} 96 \%$ ethanol for 6 to $24 \mathrm{~h}$ and measured before and after addition of acid on a Turner Designs Model 700 Fluorometer. Chl a concentrations were converted to carbon values using a $\mathrm{C}: \mathrm{chl}$ a ratio of 30 , which was representative for a spring bloom in Danish waters (Olesen \& Lundsgaard 1995). Samples for analysis of species compositions at Koster Stn and Hirtshals Stn were preserved with Lugol's solution (acidified; $2 \%$ final concentration). The phytoplankton was counted and measured after $24 \mathrm{~h}$ of settling using inverted microscopy at 200× magnification (Utermöhl 1958). Depending on the concentration of cells in the samples, 10,25 or $50 \mathrm{ml}$ of samples were settled. Half of the chamber area was counted for cells larger than $10 \mu \mathrm{m}$, and 1 diagonal of the chamber was usually counted for cells in the size range 2 to $10 \mu \mathrm{m}$.
Primary production. Primary production was measured in samples collected from both the surface $(3 \mathrm{~m})$ and the subsurface fluorescence maximum. Where a sub-surface maximum was not present, the second sample was taken at $15 \mathrm{~m} \cdot{ }^{14} \mathrm{CO}_{2}$ (Water Quality Institute, Denmark: $40 \mu \mathrm{Ci}$ to $500 \mathrm{ml}$ ) was added and $25 \mathrm{ml}$ distributed into each of 7 acid washed Durex glass bottles. The samples were incubated at 7 photon flux densities between 0 and approximately $500 \mu \mathrm{mol}$ photons $\mathrm{m}^{2} \mathrm{~s}^{-1}$ for $2 \mathrm{~h}$ in an artificial light incubator. Samples were filtered onto GF/F filters (Whatman), acidified to remove excess $\mathrm{CO}_{2}$ and frozen until scintillation analysis. The photosynthetic characteristics, alpha and $\mathrm{P}_{\max }$ (photosynthetic efficiency and maximum photosynthesis) were determined for samples from each of the 2 depths. The photosynthesis vs light characteristics established for each sample, normalized to chlorophyll content at each given depth, were assumed to apply from the surface to the water mass in which the subsurface peak was recorded. Characteristics for the deeper sample, normalized to chlorophyll at $1 \mathrm{~m}$ depth intervals, were applied to all deeper waters down to $30 \mathrm{~m}$.

Light attenuation in the water column was measured by a Li-Cor quantameter mounted on the CTD system. By using the average photon flux density at the surface for each $\mathrm{h}$ measured during the cruise and the measured attenuation coefficient, a matrix of light describing the light climate at meter intervals throughout the day was constructed. These light values were then applied to the determined or estimated photosynthetic characteristics for the phytoplankton at $1 \mathrm{~m}$ depth intervals over the day. Summation of the cells in this second matrix yielded an estimate of daily primary production.

Phytoplankton growth, $\mu\left(\mathrm{d}^{-1}\right)$, was estimated as the ratio between primary production and phytoplankton biomass in carbon units $(\mu=\mathrm{PP} / \mathrm{PB})$.

Heterotrophic bacteria and nanoflagellates. $5 \mathrm{ml}$ samples for counts of heterotrophic bacteria and $10 \mathrm{ml}$ samples for nanoflagellates were preserved with buffered formalin at a final concentration of $2 \%$ and filtered onto black Nucleopore filters $(0.2$ and $0.8 \mu \mathrm{m}$, respectively), stained with acridine orange (Hobbie et al. 1977 for bacteria) and DAPI (Porter \& Feig 1980 for flagellates), stored at $-20^{\circ} \mathrm{C}$ and counted within 2 mo after the end of the cruise. Autofluorescence of phototrophic nanoflagellates (PNF) was distinguished under blue light excitation. Nanoplankton were divided into 4 size classes $(<3,3$ to 5,5 to 7 , and 7 to $10 \mu \mathrm{m})$ and the biovolumes were estimated from linear dimensions as prolate spheroids (Verity et al. 1992). Abundance of bacteria and the biovolume for flagellates were converted into biomass using $20 \mathrm{fg} \mathrm{C} \mathrm{cell}^{-1}$ (Lee \& Fuhrman 1987) and $183 \mathrm{fgC}^{-3}{ }^{-3}$ (Caron et al. 1995), respectively. 
Bacterial production was estimated by the thymidine method (Fuhrman \& Azam 1980). Duplicate samples $(10 \mathrm{ml})$ and a control (formalin $2 \%$ final concentration added immediately after label addition) were incubated with $10 \mathrm{nM}$ [Methyl- $\left.{ }^{3} \mathrm{H}\right]$ thymidine $\left({ }^{3} \mathrm{H}-\mathrm{Tdr}, 25 \mathrm{Ci}\right.$ $\mathrm{mmol}^{-1}$ ) at in situ temperature for $2 \mathrm{~h}$ in the dark. Bacterial production was estimated from ${ }^{3} \mathrm{H}$-Tdr incorporation rates by using a conversion factor of $1.1 \times 10^{18}$ cells mol $\operatorname{Tdr}^{-1}$ (Riemann et al. 1987). Bacterial growth rate $\mu$ $\left(\mathrm{d}^{-1}\right)$ for in situ measurements was calculated as the ratio of bacterial production to bacterial biomass $(\mu=$ $\mathrm{BP} / \mathrm{BB})$. The carbon demand by bacteria was estimated from a growth efficiency of $27 \%$ (Giorgio \& Cole 2000).

Long-term incubations ( $48 \mathrm{~h})$ were used to estimate (1) the grazing of bacteria by nanoflagellates $(<20 \mu \mathrm{m}$ size fraction) relative to the whole protozoan community $(<100 \mu \mathrm{m}$ size fraction) and (2) nanoflagellate growth in the $<20 \mu \mathrm{m}$ size fraction. Seawater for these experiments was collected at the fluorescence peak and at $40 \mathrm{~m}$. Triplicate bottles of 100 and $20 \mu \mathrm{m}$ gently screened seawater and control bottles $(0.8 \mu \mathrm{m}$ gently filtered water) were inoculated with $0.5 \times 10^{5} \mathrm{ml}^{-1}$ monodispersed fluorescently labeled bacteria (FLB) Pseudomonas diminuta (volume $0.064 \mu^{3}$ ). FLB were prepared according to Vazquez-Dominguez et al. (1999). Subsamples for counts of bacteria, flagellates and bacterial production were withdrawn from the bottles at time zero and after 24 and $48 \mathrm{~h}$. Incubation was performed at in situ temperature in the dark. Grazing rates on bacteria were obtained by measuring the rate of disappearance of FLB in $<20$ and $<100 \mu \mathrm{m}$ fractions of seawater after subtracting the FLB disappearance in the control. Calculation of grazing and growth rates was performed according to Salat \& Marrasé (1994) assuming a growth efficiency of $40 \%$.

Ciliates and heterotrophic dinoflagellates $>\mathbf{2 0} \mathbf{\mu m}$. Samples for estimation of biomass were collected from the depth of the fluorescence maximum (FM), at 5 or $20 \mathrm{~m}$ (depending on the depth of FM) and at $40 \mathrm{~m}$. The samples were fixed in $2 \%$ Lugol's solution and settled in 10 or $50 \mathrm{ml}$ chambers for $24 \mathrm{~h}$ and counted and identified under an inverted microscope. The identification of species or morphological types was based on Nielsen \& Hansen (1999). All naked dinoflagellates $>20 \mu \mathrm{m}$ were considered as heterotrophic according to season investigations in the Kattegat (Hansen 1991) and in the Disko Bay (Levinsen et al. 1999). Cell volumes $\left(\mu \mathrm{m}^{3}\right)$ were estimated from measurements of linear dimensions and assuming simple geometrical shapes. Carbon biomass (pgC cell ${ }^{-1}$ ) was calculated according to Menden-Deuer \& Lessard (2000). The carbon demands $\left(\mathrm{d}^{-1}\right)$ of ciliates and heterotrophic dinoflagellates $>20 \mu \mathrm{m}$ were estimated by assuming a log-log linear relationship between maximum ingestion rate and cell volume and $\mathrm{a}_{10}$ of 2.8 according to
Hansen et al. (1997b). A growth efficiency of 33\% was used to calculate the production of microzooplankton (Hansen et al. 1997b).

Mesozooplankton. Samples for the determination of mesozooplankton biomass in the upper $100 \mathrm{~m}$ were collected by a submersible pump (3000 $\left.1 \mathrm{~min}^{-1}\right)$ equipped with a $45 \mu \mathrm{m}$ net. On the Koster and Hirtshals stations, 5 strata were sampled: 0 to 10,10 to 25 , 25 to 40,40 to 60 and 60 to $100 \mathrm{~m}$, while only 2 strata, 0 to $25 \mathrm{~m}$ and 25 to $100 \mathrm{~m}$, were sampled on the transect stations. After collection, the samples were concentrated on a $30 \mu \mathrm{m}$ sieve and fixed in $2 \%$ buffered formalin (final concentration). In the laboratory, the mesozooplankton were counted and their lengths measured. The carbon biomass was calculated from the abundance and the length:weight relationship according to literature values (Klein Breteler et al. 1982, Berggreen et al. 1988, Hansen \& Ockelmann 1991, Hay et al. 1991, Hirche \& Mumm 1992, Hansen 1993, Sabatini \& Kiørboe 1994, Hansen et al. 1997a, Fotel et al. 1999, Satapoomin 1999).

The grazing rates of the copepods were estimated using 2 approaches: (1) from the specific egg production rates and (2) from the gut fluorescence and gut clearance experiments. Egg production experiments were conducted with 2 species, Acartia clausi and Calanus finmarchicus. Copepods for the egg production experiments were collected from the upper $25 \mathrm{~m}$ using a WP-2 net (mesh size $200 \mu \mathrm{m}$ ) with a large nonfiltering cod end. Due to the high densities of diatoms and clogging of the net, additional hauls were taken with a coarser WP-3 net $(450 \mu \mathrm{m})$ to get enough $C$. finmarchicus for the experiments. Immediately after collection, the contents of the cod end were transferred to a thermobox, diluted with surface water and brought to the laboratory. During the sorting of the copepods, warming was avoided by placing the sample in a Petri dish with ice. Within $1 \mathrm{~h}$, females were transferred to $600 \mathrm{ml}$ polycarbonate incubation bottles with $45 \mu \mathrm{m}$ filtered water. Ten replicate bottles, each containing 2 females of C. finmarchicus and 4 to 10 bottles with 3 females of $A$. clausi each were incubated for $24 \mathrm{~h}$ at $5^{\circ} \mathrm{C}$ in the dark on a rotating plankton wheel $(2 \mathrm{rpm})$. After incubation, the spawned eggs were counted and the length of the females and diameters of the eggs were measured. The specific egg production (SEP, $\mathrm{d}^{-1}$ ) was calculated from the carbon content of females and eggs, where egg volume was converted to carbon

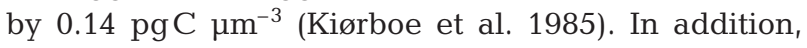
Oithona spp. eggs and females were counted in the biomass samples and the egg/female ratio was estimated. Population SEP rates were calculated from the egg/female-ratios, carbon content of eggs and females, and temperature-dependent hatching rates according to Nielsen et al. (2002). Total copepod secondary pro- 
Table 1. The identified water masses and their characteristics. The range of minimum values of temperature and salinity are the minimum values from each CTD profile within the water mass. Nutrient values are mean \pm SD from $5 \mathrm{~m}$ in W1, W2 and W3 and from $40 \mathrm{~m}$ in $\mathrm{W} 4$

\begin{tabular}{|lcccc|}
\hline & Water mass 1 & Water mass 2 & Water mass 3 & Water mass 4 \\
\hline Min. salinity $(\mathrm{psu})$ & $29.3-31.4$ & $27.7-29.3$ & $28.9-30.9$ & $>34$ \\
Min. temp. $\left({ }^{\circ} \mathrm{C}\right)$ & $3.8-3.9$ & $3.2-3.5$ & $3.6-3.9$ & $>4.5$ \\
Max. chl $a\left(\mu \mathrm{g} \mathrm{l}^{-1}\right)$ & $10-12$ & $20-25$ & $11-25$ & $<1$ \\
Surface $\mathrm{N}: \mathrm{P}$ ratio & $9-14$ & $0-1$ & $0-2$ & $14-17$ \\
Phosphate $(\mu \mathrm{M})$ & $0.63 \pm 0.02$ & $0.42 \pm 0.10$ & $0.31 \pm 0.17$ & $0.49-0.07$ \\
Silicate $(\mu \mathrm{M})$ & $6.9 \pm 0.8$ & $4.4 \pm 1.6$ & $3.2 \pm 2.0$ & $4.8 \pm 0.4$ \\
Stations & Koster Stn $(0-12 \mathrm{~h})$ & Koster Stn $(18-48 \mathrm{~h})+\mathrm{T} 1$ & $\mathrm{~T} 2, \mathrm{~T} 3, \mathrm{~T} 4+$ Hirtshals Stn & All \\
Date $(\mathrm{dd} / \mathrm{mm} / \mathrm{yy})$ & $20 / 3 / 99$ & $21-24 / 3 / 99$ & $24-27 / 3 / 99$ & $20-27 / 3 / 99$ \\
Name & Skagerrak water & Baltic water outflow & Skagerrak water & Bottom water \\
& & & & \\
\hline
\end{tabular}

duction was estimated as the sum of (1) C. finmarchicus carbon biomass multiplied by their SEP rate, (2) the remaining calanoid carbon biomass multiplied by the SEP rate of $A$. clausi assuming that this species was representative for all stages of calanoid species, and (3) cyclopoid carbon biomass multiplied by the SEP rate of Oithona spp.

At the 2 intensively sampled stations, samples for gut fluorescence were taken immediately after the $450 \mu \mathrm{m}$ net was brought on board. Three females of Calanus finmarchicus were transferred to $5 \mathrm{ml}$ of $96 \%$ ethanol (10 replicates) and extracted in the refrigerator overnight. The gut contents of chl a and phaeopigments were calculated according to Båmstedt et al. (2000) and converted to carbon by a factor of 30 (Olesen \& Lundsgaard 1995).

Two gut clearance experiments were performed with 200 females of Calanus finmarchicus transferred to a 31 polycarbonate bottle containing a concentrated phytoplankton sample $\left(61 \mu \mathrm{g} \mathrm{chl} \mathrm{a}{ }^{-1}\right)$. The females were allowed to graze for $1 \mathrm{~h}$ at $5^{\circ} \mathrm{C}$ in dim light before they were gently washed with GF/F-filtered surface water onto a $200 \mu \mathrm{m}$ sieve and transferred to a $10 \mathrm{l}$ bucket containing GF/F-filtered surface water. Five samples of 3 to 5 females were taken after $0,5,15,30,45$ and 60 , 90,120 and $300 \mathrm{~min}$ and transferred to $5 \mathrm{ml}$ of $96 \%$ ethanol. After overnight extraction, the samples were measured on a Turner Designs Model 700 Fluorometer. Gut clearance rate was estimated as the slope of log (gut fluorescence) vs incubation time (60 min).

Total ingestion by copepods was calculated as the sum of (1) carbon biomass of Calanus finmarchicus multiplied by the specific ingestion rate (estimated with the gut fluorescence method) and (2) remaining carbon biomass multiplied by SEP rate of Acartia clausi for calanoids and SEP rate of Oithona spp. for cyclopoids and all divided by a growth efficiency of $33 \%$. Ingestion by nauplii was calculated as the nauplii biomass multiplied by the mean ingestion of $C$. finmarchicus and A. clausi.
Meroplankton larvae and rotifer growth rates were estimated from Hansen (1993) and Hansen et al. (1997a), respectively. Ingestion rate by meroplankton and rotifers was calculated as the carbon biomass multiplied by the specific growth rates and divided by a growth efficiency of $33 \%$.

\section{RESULTS}

\section{Hydrography}

The water column exhibited a sharp pycnocline located at 5 to $12 \mathrm{~m}$ depth, and surface temperatures were 3.5 to $4.5^{\circ} \mathrm{C}$ (Fig. 2). Three surface water masses ('W1 to W3') and 1 bottom water mass ('W4') could be identified in the study area during the cruise based on their temperature, salinity and bio-geochemical characteristics (Table 1). The different parameters were plotted against each other to allow separation of the different water masses (Fig. 3). According to the T-S diagram, W1 and W3 belong to the same water mass ('Skagerrak water') characterized by relatively high salinity (29.3 to $31.4 \mathrm{psu}$ ) and temperature (3.8 to $3.9^{\circ} \mathrm{C}$ ). However, W1 exhibited a higher surface N/P ratio and lower chl a concentration compared to W3, which indicates that they are different in age and degree of nutrient depletion. W1 was encountered at the Koster Stn during the first $12 \mathrm{~h}$ of sampling and W3 was found at Stns T2 to T4 and Hirtshals Stn during the period 24 to 27 March. A somewhat lower salinity and temperature distinguish W2, which appears at Koster Stn during Hours 18 to 48 of sampling and at Stn T1. W2 presumably represents outflow from the Kattegat/Baltic Sea. W4 was distinguished from the surface water masses by having a temperature of $>4.5^{\circ} \mathrm{C}$ and a salinity of $>34$ psu.

We then wanted to investigate if the growth and biomass of the organisms were dependent upon the water mass where they live or if they were identical in the 


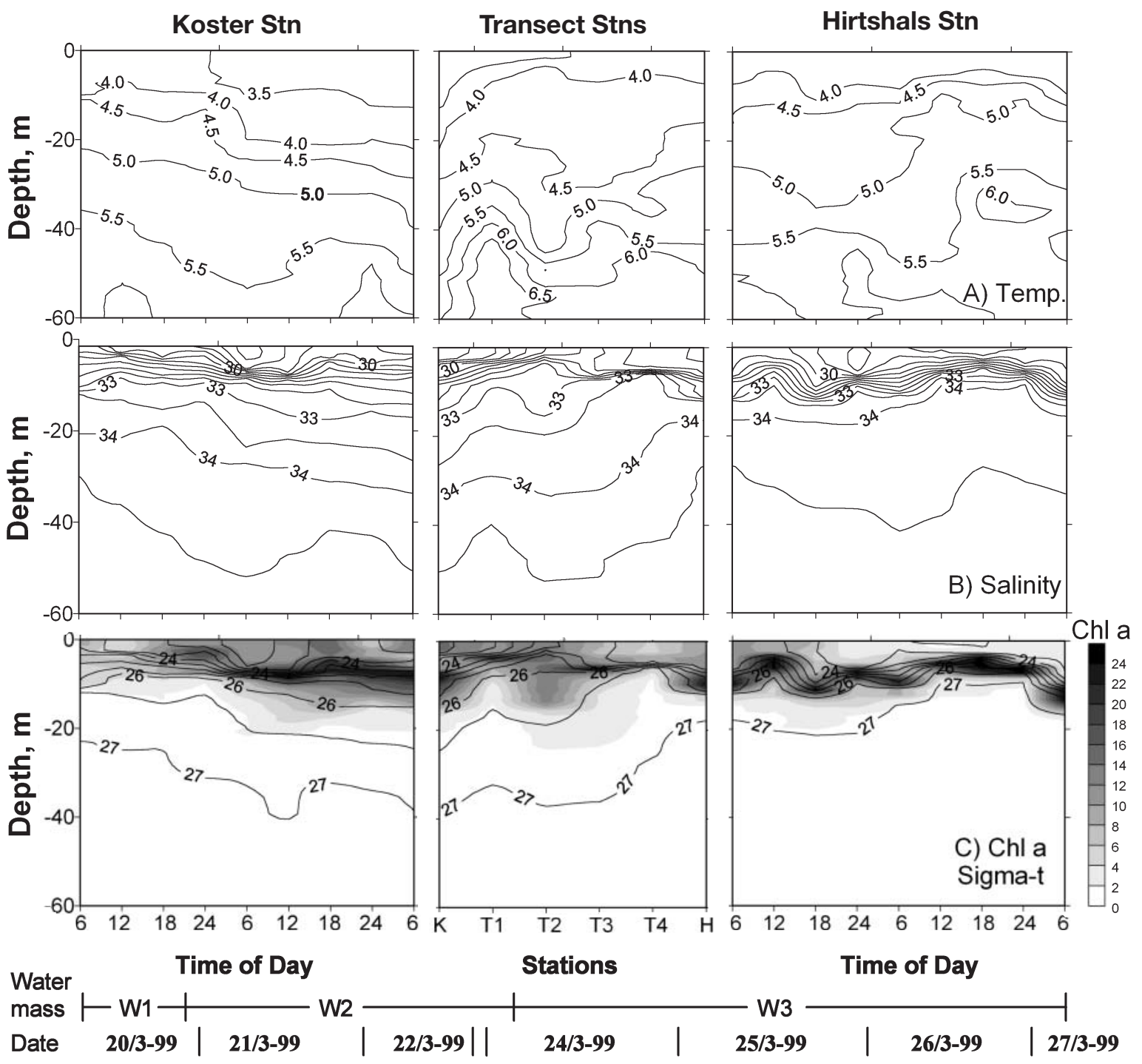

Fig. 2. Isopleth diagrams of (A) temperature $\left({ }^{\circ} \mathrm{C}\right)$, (B) salinity (psu), (C) density (sigma-t) and chl a $\left(\mu g \mathrm{l}^{-1}\right)$ for Koster Stn and Hirtshals Stn with time $(48 \mathrm{~h})$ and for the transect stations (K-48h, T1, T2, T3, T4, H-Oh)

Table 2. The average \pm SD of biomass, composition and growth rates in the water masses W1, W2 and W3. There was a significant difference between the water masses W2 $(\mathrm{n}=7)$ and W3 $(\mathrm{n}=12)$ for the parameters indicated with * $(\mathrm{p}<0.05$; ANOVA). For statistical analyses, all parameters were log-transformed to assure normal distribution. W1 was not included in the test because of too few replicates

\begin{tabular}{|c|c|c|c|c|c|c|c|c|c|c|c|}
\hline $\begin{array}{l}\text { Water } \\
\text { mass }\end{array}$ & $\begin{array}{c}\text { Chl a } \\
\text { conc. } \\
\left(\mathrm{mg} \mathrm{m}^{-2}\right)\end{array}$ & $\begin{array}{c}\text { Chl } a \\
0 \text { to } 10 \mu \mathrm{m} \\
\quad(\%)\end{array}$ & $\begin{array}{c}\text { Chl a } \\
10 \text { to } 45 \mu \mathrm{m} \\
(\%)\end{array}$ & $\begin{array}{c}\text { Chl } a \\
45 \text { to } 200 \mu \mathrm{m} \\
(\%)\end{array}$ & $\begin{array}{c}\text { Chl a } \\
>200 \mu \mathrm{m} \\
(\%)\end{array}$ & $\begin{array}{l}\text { Phytopl. } \\
\text { growth } \\
\left(\mathrm{d}^{-1}\right)\end{array}$ & $\begin{array}{l}\text { Bacterial } \\
\text { biomass } \\
\left(\mathrm{mg} \mathrm{C} \mathrm{m}^{-2}\right)\end{array}$ & $\begin{array}{l}\text { Bacteria } \\
\text { growth } \\
\left(\% d^{-1}\right)\end{array}$ & $\begin{array}{c}\text { HNF } \\
\text { biomass } \\
\left(\mathrm{mgC} \mathrm{m}^{-2}\right)\end{array}$ & $\begin{array}{c}\text { H-dino } \\
\text { biomass } \\
\left(\mathrm{mg} \mathrm{C} \mathrm{m}^{-2}\right)\end{array}$ & $\begin{array}{c}\text { Ciliate } \\
\text { biomass } \\
\left(\mathrm{mgC} \mathrm{m}^{-2}\right)\end{array}$ \\
\hline W1 & $78 \pm 10$ & $8 \pm 6$ & $16 \pm 9$ & $35 \pm 14$ & $40 \pm 6$ & $0.92 \pm 0.27$ & $324 \pm 77$ & $6.2 \pm 2.6$ & $28 \pm 2$ & $41 \pm 4$ & $61 \pm 20$ \\
\hline W2 & $239 \pm 69$ & $17 \pm 4$ & $14 \pm 9$ & $33 \pm 11$ & $35 \pm 6$ & $0.34 \pm 0.19$ & $419 \pm 90$ & $3.7 \pm 1.4$ & $30 \pm 14$ & $129 \pm 20$ & $107 \pm 21$ \\
\hline W3 & $229 \pm 98$ & $25 \pm 10^{*}$ & $20 \pm 6$ & $32 \pm 5$ & $24 \pm 6^{*}$ & $0.31 \pm 0.17$ & $403 \pm 73$ & $8.7 \pm 3.0^{*}$ & $160 \pm 135^{*}$ & $171 \pm 87$ & $109 \pm 37$ \\
\hline $\begin{array}{l}\text { Water } \\
\text { mass }\end{array}$ & $\begin{array}{l}\text { H-dino./ } \\
\text { ciliate } \\
\text { ratio }\end{array}$ & $\begin{array}{c}\text { Rotifer } \\
\text { biomass } \\
\left(\mathrm{mg} \mathrm{C} \mathrm{m}^{-2}\right)\end{array}$ & $\begin{array}{l}\text { Meropl. } \\
\text { biomass } \\
\left(\mathrm{mgC} \mathrm{m}^{-2}\right)\end{array}$ & $\begin{array}{l}\text { Copepod } \\
\text { biomass } \\
\left(\mathrm{mg} \mathrm{C} \mathrm{m}^{-2}\right)\end{array}$ & $\begin{array}{l}\text { Large } \\
\text { copepods } \\
(\%)\end{array}$ & $\begin{array}{l}\text { Small } \\
\text { copepods } \\
(\%)\end{array}$ & $\begin{array}{c}\text { Nauplii } \\
\text { biomass } \\
\left(\mathrm{mg} \mathrm{C} \mathrm{m}^{-2}\right)\end{array}$ & $\begin{array}{c}\text { Calanus } \\
\text { ingestion } \\
\left(\% \mathrm{~d}^{-1}\right)\end{array}$ & $\begin{array}{c}\text { Calanus } \\
\text { SEP } \\
\left(\% \mathrm{~d}^{-1}\right)\end{array}$ & $\begin{array}{l}\text { Acartia } \\
\text { SEP } \\
\left(\% d^{-1}\right)\end{array}$ & $\begin{array}{c}\text { Oithona } \\
\text { SEP } \\
\left(\% d^{-1}\right)\end{array}$ \\
\hline W1 & $0.72 \pm 0.21$ & $2 \pm 1$ & $41 \pm 31$ & $57 \pm 8$ & $54 \pm 7$ & $46 \pm 7$ & $31 \pm 15$ & $25 \pm 12$ & $2.1 \pm 0.4$ & $4.0 \pm 2.2$ & $3.4 \pm 1.2$ \\
\hline W2 & $1.21 \pm 0.17$ & $14 \pm 9$ & $84 \pm 45$ & $146 \pm 48$ & $48 \pm 11$ & $52 \pm 11$ & $106 \pm 49$ & $19 \pm 4$ & $4.4 \pm 1.0$ & $5.3 \pm 1.8$ & $2.9 \pm 0.9$ \\
\hline W3 & $1.54 \pm 0.53$ & $12 \pm 8$ & $73 \pm 38$ & $188 \pm 42^{*}$ & $59 \pm 9^{*}$ & $41 \pm 9^{*}$ & $77 \pm 43$ & $21 \pm 4$ & $2.4 \pm 0.6^{*}$ & $4.8 \pm 1.3$ & $2.5 \pm 0.8$ \\
\hline
\end{tabular}


Skagerrak area regardless of water masses. Therefore we tested if there was a significant difference in the biological parameters (Table 2) between the surface water masses. It was not possible to use a PCA or MANOVA because the correlations between the biological variables were very low. Instead we used, in this case, the more powerful separate ANOVAs $(\mathrm{p}<0.05)$ (Table 2).

Nitrate and nitrite were depleted in the surface layers of $\mathrm{W} 2$ and $\mathrm{W} 3$, while the average $( \pm \mathrm{SD})$ in $\mathrm{W} 1$ was $7.2 \pm 1.4 \mu \mathrm{M}$. Surface values of phosphate $(0.63 \pm$ $0.02 \mu \mathrm{M})$ and silicate $(6.9 \pm 0.8 \mu \mathrm{M})$ were also higher in $\mathrm{W} 1$ than in W2 and W3. Accordingly, the N/P ratio was higher (9 to 14) in W1 compared to W2 and W3, where the ratio was 0 to 2 .

\section{Phytoplankton}

High concentrations of chl a were found throughout the upper $20 \mathrm{~m}$ of the water column but a chl a maximum was nearly always observed in association with the pycnocline (Fig. 2). The biomass, potential production and growth rates of the phytoplankton per unit surface area were integrated down to $20 \mathrm{~m}$ as the majority of primary and secondary production took place here (Figs. 2, 4 $\& 5$ ). The euphotic zone (defined as the depth of $1 \%$ light penetration) had a depth of 12 to $20 \mathrm{~m}$. However, irradiance was relatively low due to cloud and snow conditions. The depth-integrated biomass and the calculated growth rates are shown in Figs. 6 \& 7, respectively.

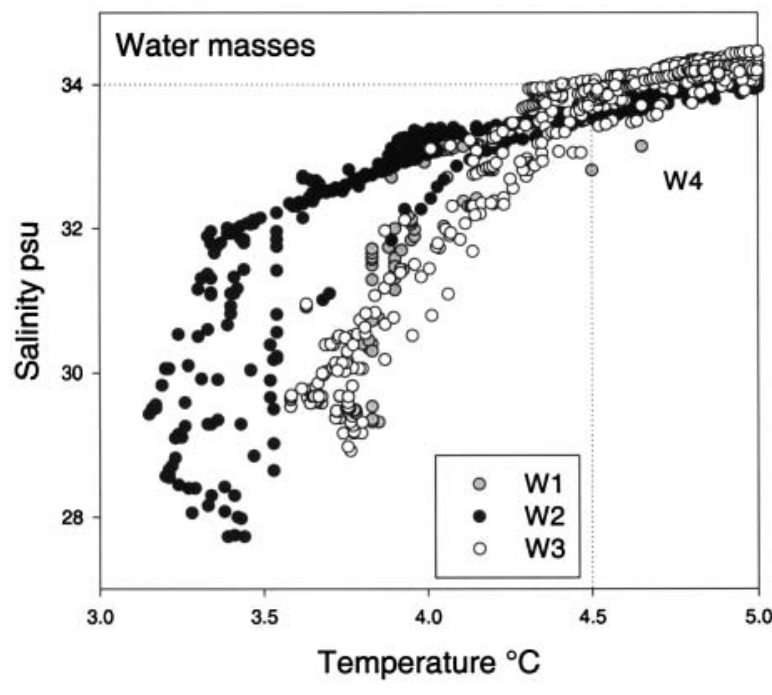

Fig. 3. Salinity-temperature plot for the different water masses. W1 and W3 (Skagerrak water) have a similar S-T plot, but differ in biogeochemical composition (Table 1). Bottom water was defined as having a salinity $>34$ psu and temperatures $>4.5^{\circ} \mathrm{C}$ and is separated from the surface water masses with a dotted line

The mean depth-integrated chl a biomass was considerably lower in W1 $\left(78 \mathrm{mg} \mathrm{m}^{-2}\right)$ than the mean values found in W2 and W3 (229 to $239 \mathrm{mg} \mathrm{m}^{-2}$ ). Large cells $(>45 \mu \mathrm{m})$ contributed 75,68 and $56 \%$ of the chl a biomass in W1, W2 and W3, respectively. In general, diatoms dominated the phytoplankton biomass, and

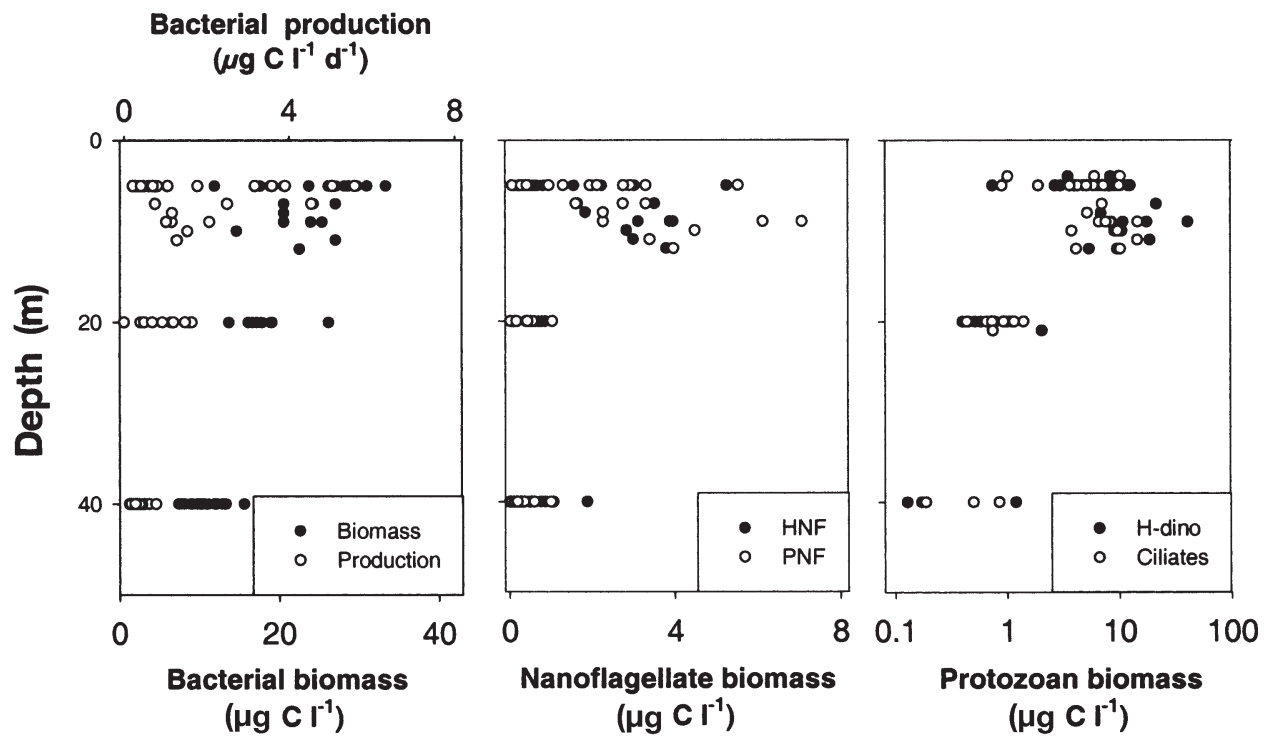

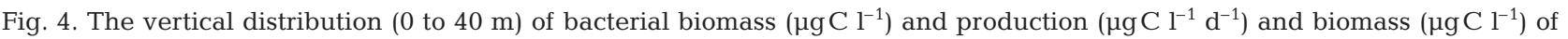
heterotrophic (HNF) and phototrophic (PNF) nanoflagellates, ciliates and heterotrophic dinoflagellates (H-dino) for all stations. 
the most abundant genera and species were Coscinodiscus sp., Chaetoceros spp., Rhizosolenia spp., Thalassiosira spp., Nitzschia spp., Leptocylindricus spp. and Skeletonema costatum. Two of the diatom species, Ditylum brightwellii and Asterionella glacialis only occurred in W3. Ceratium tripos, C. fusus, Phaeocystis pouchetii, Dictyocha speculum and Pyramimonas sp. were present in all water masses, although in lesser numbers. The 480/665 absorption ratio ranged between 0.8 to 1.2 for all water masses and was, thus, lower than the critical value of 2.0, which indicates nutrient depletion (Heath et al. 1990). The potential phytoplankton growth rate decreased with time at the Koster Stn and was on average higher in W1 $\left(0.92 \mathrm{~d}^{-1}\right)$ than in W2 and W3 (0.31 to $\left.0.34 \mathrm{~d}^{-1}\right)$.

\section{Bacteria and nanoflagellates}

Bacterial abundance was on the order of $10^{5}$ to $10^{6} \mathrm{ml}^{-1}$, corresponding to 8 to $31 \mathrm{mgC} \mathrm{m}^{-3}$. Abundance decreased slightly with depth, and bacterial production was highest in the upper $20 \mathrm{~m}$ of the water column (Fig. 4). The depth-integrated bacterial bio- mass varied little and was, on average, highest in W2 to W3 with 403 and $419 \mathrm{mgC} \mathrm{m}^{-2}$, respectively. The bacterial growth rate was significantly (ANOVA, p < $0.05)$ higher in W3 $\left(0.087 \mathrm{~d}^{-1}\right)$ than in W2 $\left(0.037 \mathrm{~d}^{-1}\right)$, while W1 exhibited intermediate growth rates $(0.062$ $\mathrm{d}^{-1}$ ). There was no correlation between bacterial production and primary productivity $\left(\mathrm{R}^{2}=0.21\right.$, $\left.\mathrm{p}>0.05\right)$, but bacterial production was overall positively correlated to Calanus-ingestion $\left(\mathrm{R}^{2}=0.64, \mathrm{p}<0.05\right)$ calculated from gut fluorescence (Fig. 8).

Heterotrophic and autotrophic nanoflagellates (HNF) were most abundant in the surface layer (0 to $20 \mathrm{~m}$ ) with $10^{2}$ to $10^{3}$ cells $\mathrm{ml}^{-1}$ (Fig. 4), with a dominance of cells $<3 \mu \mathrm{m}$. The mean depth-integrated biomass of HNF was significantly (ANOVA, p < 0.05) higher in W3 (160 $\mathrm{mgC} \mathrm{m}^{-2}$ ) than in the other water masses (28 to $30 \mathrm{mg} \mathrm{C} \mathrm{m}^{-2}$ ) and the growth rate was estimated to $0.37 \mathrm{~d}^{-1}$ in both 48 -h experiments. Grazing experiments with FLB showed that 80 to $110 \%$ of the bacterial production was grazed per day and that most of the grazing on bacteria ( $>80 \%$ ) was due to the $<20 \mu \mathrm{m}$ size-fraction (HNF); i.e. ciliates and other predators played a minor role in bacterial consumption.
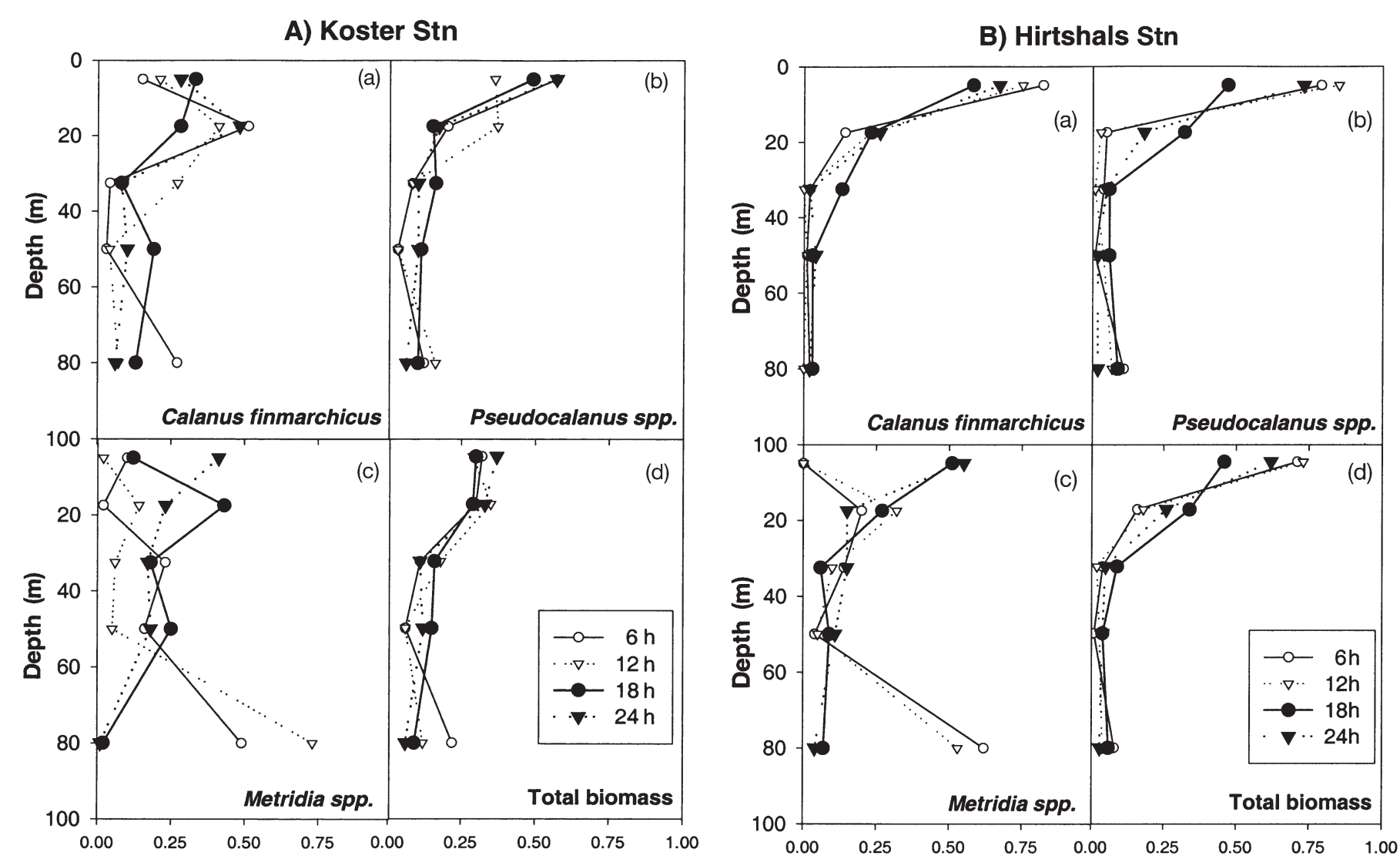

Fig. 5. Relative depth distribution of biomass of the dominant copepod species: (a) Calanus finmarchicus, (b) Pseudocalanus spp., (c) Metridia spp. and (d) total biomass 


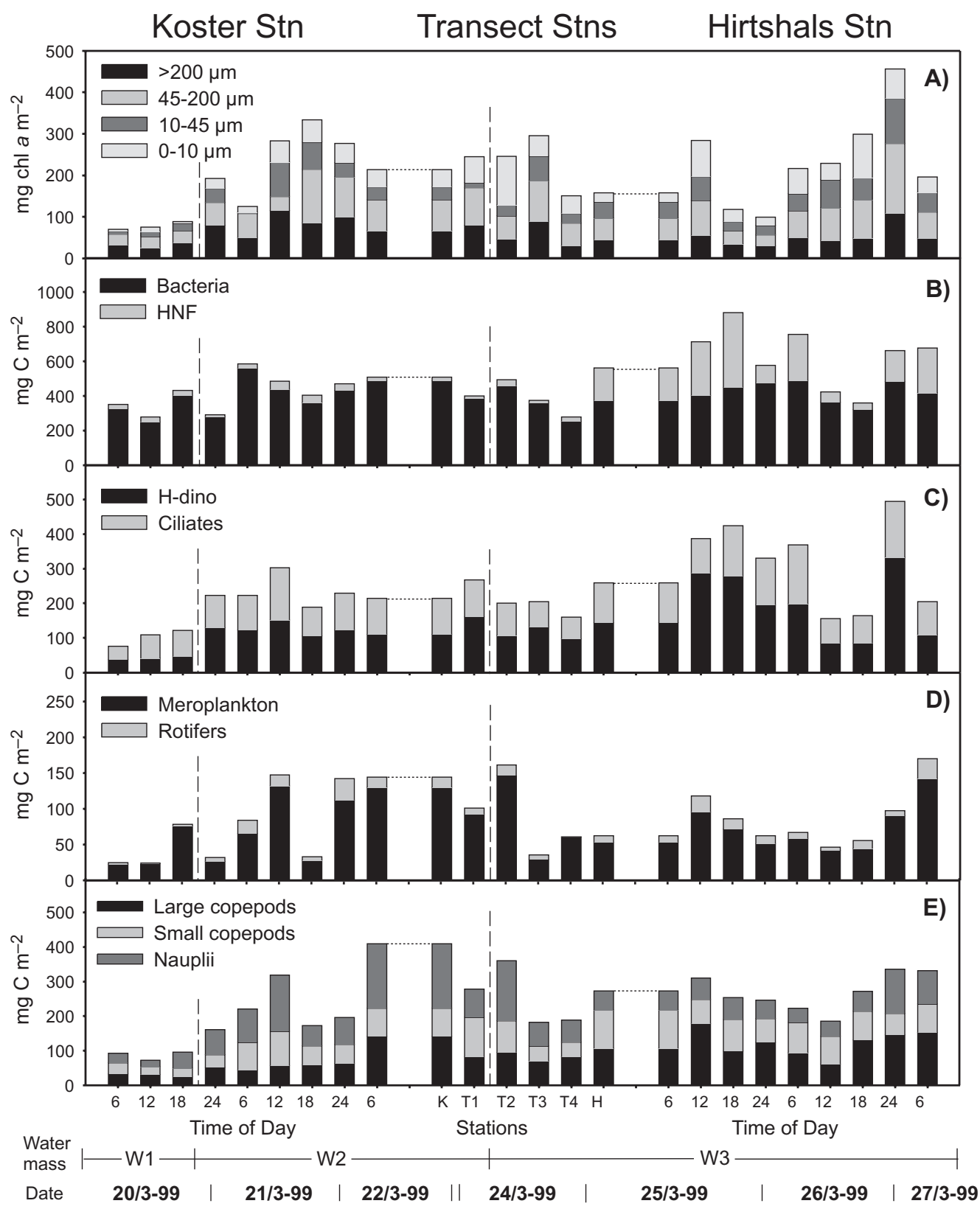

Fig. 6. The depth-integrated biomass (0 to $20 \mathrm{~m}$ ) for (A) phytoplankton ( $\mathrm{mg} \mathrm{chl} \mathrm{a} \mathrm{m}^{-2}$ ), and for (B) bacteria and heterotrophic nanoflagellates (HNF), (C) heterotrophic dinoflagellates (H-dino) and ciliates, (D) mesoplankton and rotifers and (E) copepods $\left(\mathrm{mg} \mathrm{C} \mathrm{m}^{-2}\right)$ for Koster Stn and Hirtshals Stn with time and for Transect Stns. The separation of water masses (W1, W2 and W3) is indicated with vertically dashed lines

\section{Ciliates and heterotrophic dinoflagellates $>20 \mu \mathrm{m}$}

The abundance of ciliates and heterotrophic dinoflagellates $>20 \mu \mathrm{m}$ (H-dino) ranged between 0.2 and 24 cells $\mathrm{ml}^{-1}$ in the surface layer. The biomass of ciliates and H-dino peaked at the chl a maximum with values up to 17 and $40 \mathrm{mgC} \mathrm{m}^{-3}$, respectively, and were most substantial in the upper $20 \mathrm{~m}$ of the water column (Fig. 4). The depth-integrated biomass (0 to $20 \mathrm{~m}$ ) of H-dino was highest in W3 with $171 \mathrm{mg} \mathrm{C} \mathrm{m}^{-2}$ while, for ciliates, it was similar in W2 and W3 (107 to $109 \mathrm{mg} \mathrm{C} \mathrm{m}^{-2}$ ) and 2 to 4 times lower in W1 for both groups of protozooplankton.

The ratio between $\mathrm{H}$-dino and ciliates increased from W1 (0.72) to W2 (1.21) and, finally, W3 (1.54). The dinoflagellates were dominated by naked forms, 


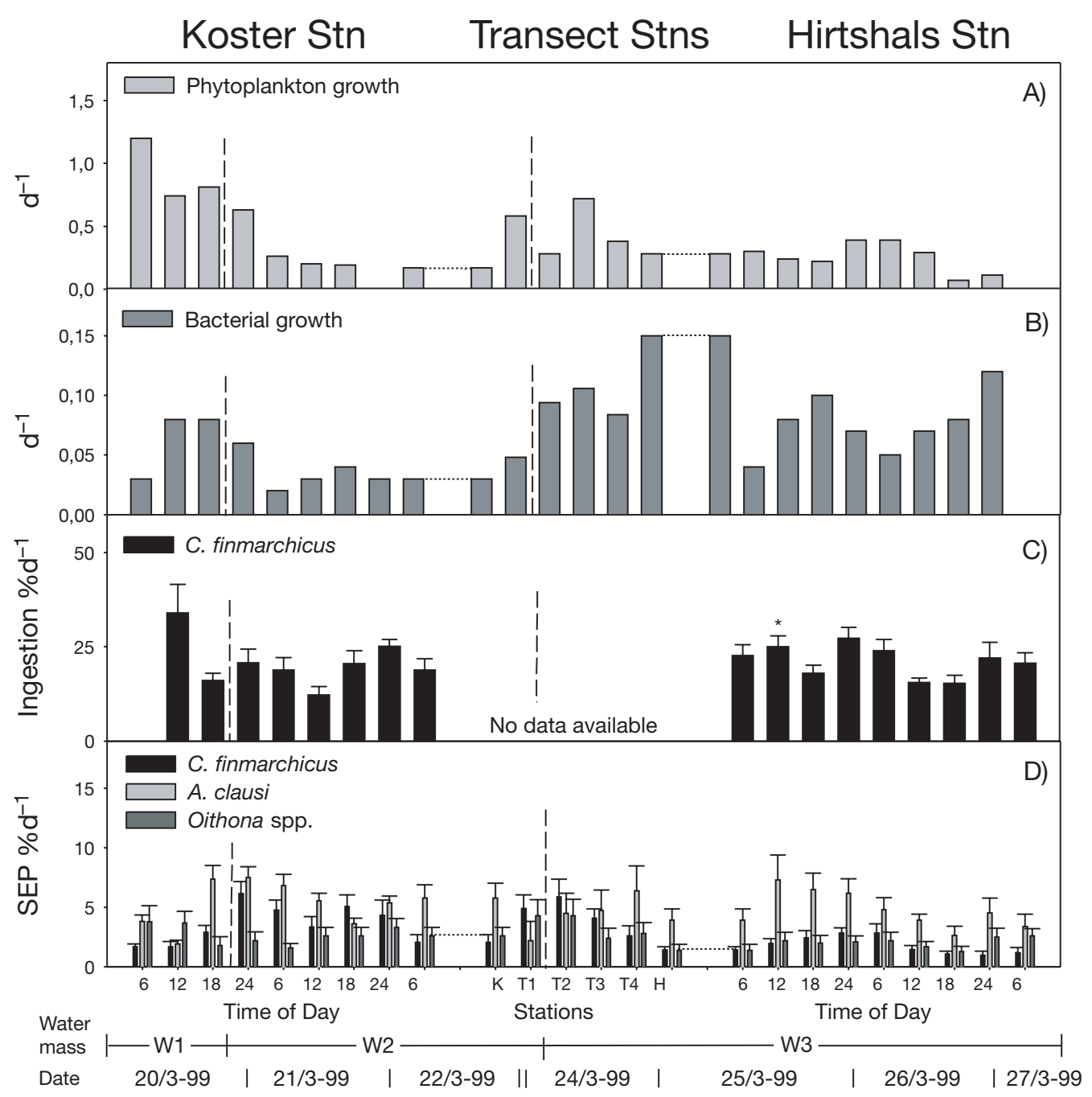

Fig. 7. The community-specific growth rates $(0$ to $20 \mathrm{~m})$ for (A) phytoplankton $\left(\mathrm{d}^{-1}\right)$ and (B) bacteria ( $\left.\mathrm{d}^{-1}\right)$, (C) specific ingestion by Calanus finmarchicus $\left(\% \mathrm{~d}^{-1}\right)$, and $(\mathrm{D})$ the specific egg production $\left(\mathrm{SEP}, \% \mathrm{~d}^{-1}\right)$ for Calanus finmarchicus, Acartia clausi and Oithona similis. The value marked with * was not included in the test of diel cycles

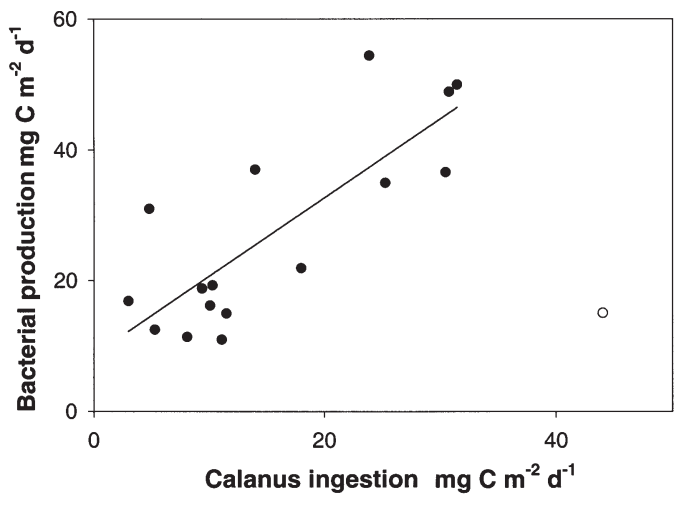

Fig. 8. Positive linear correlation $\left(\mathrm{R}^{2}=0.64, \mathrm{p}<0.01\right)$ between bacterial production and ingestion of Calanus finmarchicus at all stations. One outlier was ignored and marked as an open circle where Gyrodinium spirale constituted $13 \pm 6 \%( \pm \mathrm{SD})$ of total protozooplankton biomass in all water masses and other Gyrodinium/Gymnodinium species (20 to $100 \mu \mathrm{m})$ constituted $21 \pm 13 \%$ in W1 and 32 to $36 \pm 7$ to $10 \%$ in W2 + W3. The thecate dinoflagellates, Protoperidinium spp., Dinophysis norvegica, D. acuminata and Prorocentrum micans, were also well represented, constituting $12 \pm 7 \%$ of the total protozooplankton biomass in all water masses.

The ciliates present consisted primarily of the aloricate ciliates, Strombidium spp. and Strombilidium spp. These species comprised $51 \pm 12 \%$ in W1 and 31 to 40 \pm 5 to $8 \%$ of total protozooplankton biomass in W2 and W3. The mixotrophic ciliates, Mesodinium rubrum and Laboea strobila, were of minor importance at all stations $(<1.6 \pm 2 \%$ of total $)$. 
Table 3. Coefficient of variation (CV, \%) calculated as the ratio between SD and the mean for Koster, Hirtshals and Transect Stns (including K48 and H0) and for Water masses: W1, W2 and W3. The frequency of $\mathrm{CV}_{\max }\left(^{*}\right.$ ) was $10 / 14,3 / 14$ and 1/14 in K, T and $\mathrm{H}$, respectively. Mean CV was significant reduced for water masses compared to Stations (MANOVA, $p<0.05$ )

\begin{tabular}{|c|c|c|c|c|c|c|c|c|c|c|c|c|c|c|}
\hline & $\begin{array}{l}\text { Chl a } \\
\text { conc. }\end{array}$ & $\begin{array}{l}\text { Phyto. } \\
\text { growth }\end{array}$ & $\begin{array}{c}\text { Bact. } \\
\text { biomass }\end{array}$ & $\begin{array}{l}\text { Bact. } \\
\text { growth }\end{array}$ & HNF & H-dino & Ciliate & $\begin{array}{c}\text { Rotifer } \\
\text { - biomass }\end{array}$ & Meropl. & Copepod & Nauplii & $\begin{array}{l}\text { Calanus } \\
\text { SEP }\end{array}$ & $\begin{array}{l}\text { Acartia } \\
\text { SEP }\end{array}$ & $\begin{array}{l}\text { Oithona } \\
\text { SEP }\end{array}$ \\
\hline Koster Stn & $54^{*}$ & $71^{*}$ & $25^{*}$ & $50^{*}$ & 35 & 45 & $34^{*}$ & $93^{*}$ & $68^{*}$ & $50^{*}$ & $69^{*}$ & 45 & $34^{*}$ & 30 \\
\hline Transect Stns & 26 & 53 & 21 & 48 & $134^{*}$ & 19 & 22 & 58 & 54 & 26 & 58 & $50^{*}$ & 33 & $39^{*}$ \\
\hline Hirtshals Stn & 48 & 43 & 14 & 40 & 62 & $48^{*}$ & 30 & 58 & 45 & 15 & 42 & 41 & 29 & 23 \\
\hline Mean CV & 43 & 55 & 20 & 46 & 77 & 38 & 29 & 70 & 56 & 31 & 57 & 45 & 32 & 30 \\
\hline W1 & 13 & 27 & 24 & 41 & 5 & 11 & 32 & 42 & 76 & 15 & 47 & 33 & 55 & 36 \\
\hline W2 & 29 & 56 & 22 & 38 & 47 & 16 & 20 & 63 & 54 & 33 & 47 & 30 & 35 & 32 \\
\hline W3 & 43 & 54 & 18 & 34 & 84 & 51 & 34 & 65 & 52 & 22 & 56 & 60 & 27 & 34 \\
\hline Mean CV & 28 & 46 & 21 & 38 & 46 & 26 & 29 & 57 & 60 & 23 & 50 & 41 & 39 & 34 \\
\hline$\%$ difference & -34 & -17 & 4 & -17 & -41 & -32 & $\mathbf{0}$ & -18 & 8 & -23 & -12 & -10 & 21 & 12 \\
\hline
\end{tabular}

\section{Mesozooplankton}

The relative contributions of the different mesozooplankton groups to the total biomass were similar in the different water masses, and copepods dominated the mesozooplankton biomass with $65 \pm 12 \%$. Other groups in the mesozooplankton were meroplankton larvae (polychaeta, bivalvia, gastropoda, echinodermata, bryozoa) representing $28 \pm 10 \%$ of the biomass, rotifers with $6 \pm 3 \%$ and appendicularians with $0.8 \pm$ $0.6 \%$. The copepod community was mainly present in the upper $25 \mathrm{~m}$, where the biomass ranged from 1.3 to $33 \mathrm{mgC} \mathrm{m}^{-3}$. Numbers decreased with depth below the surface waters (Fig. 5).

The depth-integrated copepod biomass (0 to $25 \mathrm{~m}$ ) was lowest in $\mathrm{W} 1\left(57 \pm 8 \mathrm{mg} \mathrm{C} \mathrm{m}^{-2}\right)$ followed by $\mathrm{W} 2$ $\left(146 \pm 48 \mathrm{mg} \mathrm{C} \mathrm{m}^{-2}\right)$, which was significantly different from W3 $\left(188 \pm 42 \mathrm{mg} \mathrm{C} \mathrm{m}^{-2}\right.$ ) (ANOVA, $\left.\mathrm{p}<0.05\right)$. The dominant copepods were Calanus finmarchicus and Pseudocalanus spp. with an average of $51 \pm 12 \%$ and $24 \pm 9 \%$, respectively, of total biomass for all water masses. Metridia spp., Acartia spp., Temora spp., Paracalanus spp., Microcalanus spp., Centropages spp., Oithona spp. and Microsetella spp. each contributed with 1 to $5 \%$. The contribution of large copepod species (Calanus spp., Metridia spp.) to copepod biomass was significantly higher in W3 (54 to $59 \pm 7$ to $9 \%$ ) than in W2 $(48 \pm 11 \%)$ (ANOVA, p < 0.05). Nauplii biomass was, on the other hand, greater in W2 $(106 \pm 49 \mathrm{mgC}$ $\left.\mathrm{m}^{-2}\right)$ than in W3 $\left(77 \pm 43 \mathrm{mg} \mathrm{C} \mathrm{m}^{-2}\right)$.

Diel vertical migration was observed for Metridia spp. at both Koster Stn and Hirtshals Stn. Metridia spp. was more abundant in the lower depths (60 to $100 \mathrm{~m}$ ) during the daytime ( 6 to $12 \mathrm{~h}$ ) and ascended to the surface (upper $60 \mathrm{~m}$ ) at night (18 to $24 \mathrm{~h}$ ). Metridia spp. contributed, however, only little to total copepod biomass and the same pattern was therefore not observed for the total copepod biomass.
The mean egg production rate was $14 \pm 7( \pm \mathrm{SD}$, range: 5 to 26) eggs female ${ }^{-1} \mathrm{~d}^{-1}$ for Calanus finmarchicus and $5 \pm 2( \pm \mathrm{SD}$, range: 2 to 12$)$ eggs female $\mathrm{e}^{-1} \mathrm{~d}^{-1}$ for Acartia clausi. Egg production was converted to carbon units from the measured mean egg diameter and the mean cephalothorax size of $C$. finmarchicus $(2336 \pm 310 \mu \mathrm{m})$ and of A. clausi $(828 \pm$ $150 \mu \mathrm{m})$. The SEP for $C$. finmarchicus was significantly higher (ANOVA, p < 0.05) in W2 $\left(4.4 \% \mathrm{~d}^{-1}\right)$ than for W3 $\left(2.4 \% \mathrm{~d}^{-1}\right)$. There was no difference in SEP for A. clausi between the water masses, where the values ranged from 4.4 to $5.3 \% \mathrm{~d}^{-1}$. For Oithona spp., the mean egg/female ratio was $11.8 \pm 2.8$ and no difference in SEP $\left(2.5\right.$ to $\left.3.4 \% \mathrm{~d}^{-1}\right)$ was noted.

Specific ingestion rate of Calanus finmarchicus was calculated from the measured gut pigment content and gut clearance rate and ranged from 19 to $25 \% \mathrm{~d}^{-1}$ in all surface water masses. Gut clearance rate $( \pm \mathrm{SD})$ was estimated to $0.032 \pm 0.003 \mathrm{~min}^{-1}$ in both experiments ( $\mathrm{n}=6, \mathrm{r}^{2}=0.77$ to $\left.0.85, \mathrm{p}<0.05\right)$.

\section{Variability of the food web}

The spatio-diurnal variability in the structure of the food web was estimated as the coefficient of variation (CV) calculated for the 14 parameters in Table 3. In order to assess the variability between stations, we used the frequency of maximum $\mathrm{CV}\left(\mathrm{CV}_{\max }\right)$ for each parameter. The frequency gives the number of observations with the highest occurring $\mathrm{CV}$ for the 14 parameters. The diurnal variability was estimated for Koster Stn and Hirtshals Stn. The spatial variability was estimated for Transect stations, which included the stations $\mathrm{T} 1$ to $\mathrm{T} 4$ and the last measurement at Koster Stn (48 h) and the initial one at Hirtshals Stn $(0 \mathrm{~h})$. The frequency of $\mathrm{CV}_{\max }$ was highest at Koster Stn (10/14) and Transect stations (3/14) and indicates that 
food web variability was greater with time (h) at Koster Stn than in horizontal space $(\mathrm{km})$.

At Hirtshals Stn, the frequency of $\mathrm{CV}_{\max }$ and, hence, variability was relatively low (1/14). When water masses were considered instead of stations, the variability was significantly reduced (MANOVA, p < 0.05) (Table 3). The mean CV-values were 9 to $41 \%$ lower when analyzed across water masses for the given parameters except for biomass of bacteria, ciliates and meroplankton larvae and for SEP by Acartia spp. and Oithona spp.

The diurnal variability of the parameters in Table 2 was tested for the occurrence of diel rhythms at Hirtshals Stn, because this station was the only one influenced by a single water mass. The only detectable difference was between midnight/dawn (24:00 $\mathrm{h}$ to $6: 00 \mathrm{~h}$ ) and noon to dusk (12:00 h to $18: 00 \mathrm{~h})$. Bacterial growth and production followed a diel cycle (ANOVA, $\mathrm{p}<0.05)$ with increased growth during midnight to dawn $\left(0.10 \mathrm{~d}^{-1}\right)$ compared to $0.06 \mathrm{~d}^{-1}$ during noon to dusk. Calanus finmarchicus increased specific ingestion (calculated from gut fluorescence) during the period midnight to dawn (ANOVA, p < 0.07), while there was no diel cycle observed in the total copepod biomass (0 to $25 \mathrm{~m}$ ). However, if one high value (12:00 h, 25 March 1999) was ignored, the grazing impact by the $C$. finmarchicus was significantly higher at midnight to dawn (ANOVA, p < 0.05) than during the rest of the day.

\section{DISCUSSION}

\section{Water masses}

Plankton is characterized by a patchy distribution in time and in space. However, the degree to which the underlying mechanisms for this patchiness are physical or biological is still debated (Pinel-Alloul 1995, Wiafe \& Frid 1996, Folt \& Burns 1999).

In the present study, we observed high temporal and spatial food web variability at a $\mathrm{km}$ or $\mathrm{h}$ scale. This variability was quantified as the coefficient of variation $(\mathrm{CV}=\mathrm{SD} /$ mean $\times 100)$ with $\mathrm{CV}$-values up to $134 \%$. However, when analyzing the data, we found that up to $41 \%$ of the patchiness could be explained by the presence of different water masses. Three different surface water masses were identified by their physical (temperature, salinity) and bio-geochemical (nutrients, chl a) properties. Koster Stn and Transect Stn, which had the highest CV-values, were influenced by 2 water masses: 'Skagerrak water' (W1 or W3) and 'Baltic water outflow' (W2). Hirtshals Stn, on the other hand, showed less variability and was covered by Skagerrak water (W3) during the whole sam- pling period. The CV-values decreased for 9 out of the 14 given parameters when variation within water masses instead of stations was considered. The 9 parameters were specific growth rate of phytoplankton and bacteria, biomass of phytoplankton, heterotrophic nanoflagellates, heterotrophic dinoflagellates, ciliates, rotifers, copepods and nauplii and SEP of Calanus finmarchicus. Two of the parameters, bacterial and ciliate biomass, were not affected by the separation into water masses probably because they were more or less equally distributed at a $\mathrm{km}$ or h scale (CV $<29 \%$ ). Thus, sampling across different water masses was one of the important sources for the seeming 'patchiness' observed in this study.

The SEP of the Acartia spp. and Oithona spp., however, did not correlate well with water masses. The CV-values for SEP actually increased by the separation into water masses. One explanation for this could be that SEP was influenced by a factor not directly related to water masses. Small-scale turbulence in the surface layer, created by wind stress, tides or eddies with a duration of $\mathrm{h}$ to $\mathrm{d}$ could contribute to fine-scale variations in egg production. This was observed by Tiselius et al. (1991), who concluded that mixing and eddy formations were more important for specific egg production of Acartia clausi and Centropages hamatus than the surface currents in Skagerrak.

The feeding response of copepods to turbulence is assumed to be dome-shaped under non-saturating food conditions (Visser et al. 2001). The turbulent dissipation rate in the surface layer was on the order of $1.4 \times 10^{-7} \mathrm{~m}^{2} \mathrm{~s}^{-3}$ during the study period and hence in the lower end of the spectrum (A. Stips unpubl. data). However, were Acartia spp. and Oithona spp. food limited at the present high chl a concentrations? The maximum chl a concentrations observed corresponded to 360 to $750 \mathrm{mg} \mathrm{C} \mathrm{m}^{-3}(\mathrm{C}: \mathrm{chl} \mathrm{a}=30)$ at all stations. Around 14 to $20 \%$ of the biomass was in the optimal prey size-range (10 to $45 \mu \mathrm{m})$ for Acartia spp. and Oithona spp. Additionally, the maximum observed biomass of ciliates and heterotrophic dinoflagellates was 5 to $55 \mathrm{mg} \mathrm{C} \mathrm{m}^{-3}$ at all stations. Overall, this gives a maximum food availability of $205 \mathrm{mgC}$ $\mathrm{m}^{-3}$. Food limitation has been shown to occur at $<500 \mathrm{mgC} \mathrm{m}^{-3}$ for Acartia tonsa (Berggreen et al. 1988) and at $<200 \mathrm{mg} \mathrm{C} \mathrm{m}^{-3}$ for Oithona spp. (Sabatini \& Kiørboe 1994). Thus, they might have been foodlimited despite the very high chl a concentrations. Turbulence has also been shown to induce a prey switching behavior in $A$. tonsa from immobile to motile prey (Kiørboe et al. 1996), and Oithona spp. often prefer to graze on protozoans (Nielsen \& Sabatini 1996). Protozooplankton contain essential nutritional compounds that are important for copepod growth (Stoecker \& Capuzzo 1990, Kleppel 1993). 
Turbulent conditions might, then, occasionally stimulate SEP if they result in increased grazing on protozooplankton, which could explain some of the observed variability of SEP.

As for SEP, the variability in meroplankton larvae distribution did not follow the water masses, and the mean CV-value remained high (60\%) following the separation into water masses. The observed patchiness could be a result of patterns in reproductive behavior, as benthic adults periodically release bursts of eggs or larvae into the overlaying water. The benthos larvae are weak swimmers, and their dispersal over kilometers is mainly governed by advection (Metaxas 2001). It is therefore likely that the distributions of echinoderm larvae have well-defined boundaries and that the larvae stay in the water mass where they are spawned, as observed by Gallager et al. (1996) and Banse (1964).

A variety of studies have shown the close coupling between biological patchiness and physical processes at basin and seasonal scales, while fewer studies have considered this at finer spatio-temporal scales $(\mathrm{km}$ or h). However, Kiørboe et al. (1990) observed that changes at a $\mathrm{km}$ scale in food web structure were related to variations in the water column structure along a transect in Skagerrak in May. Talpsepp et al. (1999) showed a relationship between water masses and biological parameters such as phytoplankton species composition and bacterial abundance in the Skagerrak during summer. Gowen et al. (1998) defined 4 distinct geographical regions on the southern Malin Shelf based on the relationship between physical structures and distribution of plankton. Gallager et al. (1996) observed the distribution of the major taxonomic groups with a Video Plankton Recorder on a continuum of scales from mm to $100 \mathrm{~km}$ in the Great South Channel, Georges Bank. They all concluded that plankton patchiness at a fine scale $(\mathrm{km})$ was due to the occurrence of different water masses, pycnoclines or fronts in the area.

The occurrence of different taxonomic groups or species has often been shown to vary considerably between water masses (e.g. Angel 1992). However, in the present study, water masses contained the same phyto-, micro- and mesozooplankton species, and only the relative species compositions and growth rates changed between water masses. Thus, the whole area, regardless of water masses, was dominated by species characteristic for a bloom event. Nevertheless, these data also stress the importance of identifying the water masses in the system before the biological results can be interpreted and understood correctly. The water masses appear to set the physical frame within which the plankton organisms can interact with one another and small-scale physical processes.

\section{Temporal variability}

At Koster Stn, the high diurnal variability was due to the influence of different water masses and it was not possible to test for diel cycles. At Hirtshals Stn, on the other hand, diel rhythms of copepod feeding and bacterial production were observed. Calanus finmarchicus exhibited diel rhythms in specific feeding rate measured as gut fluorescence. This finding agreed well with earlier studies on different copepod species (Haney 1988, Tiselius 1988, Visser et al. 2001). The diurnal variability doubled the grazing impact by $C$. finmarchicus between midnight to dawn compared to the day. However, no vertical migration of copepods was observed.

Bacterial production and community growth rates were also increased by a factor of 2 in the period between midnight to dawn. Diel rhythms in bacterial activity have earlier been shown to follow either primary production or zooplankton ingestion. Fuhrman et al. (1985) and Rosenberg et al. (1990) found that diel cycles of bacterial growth rates were tightly coupled to primary production where dissolved photosynthates were released by the phytoplankton. Christaki et al. (1998) observed a weak delayed response of bacterial activity to enhanced zooplankton feeding rates during night. Those studies are from oligotrophic environments, where phytoplankton biomass is low and consists of small cells in contrast to the present study with high phytoplankton biomass and large diatom cells. The production of dissolved organic material by grazing is assumed to be more important during blooms of large phytoplankton because of higher leakage of DOM from fecal pellets, excretion and sloppy feeding by copepods (Strom et al. 1997, Møller \& Nielsen 2001). For example, a nocturnal maximum of both bacterial production and zooplankton abundance was found by Torreton et al. (1994) in a eutrophic tropical lagoon and by Simon (1994) during a spring bloom in Lake Constance.

The diel rhythm of bacterial production was apparently not accompanied by a response in the HNF or ciliate grazers as observed by Fuhrman et al. (1985), Sorokin et al. (1985) and Rosenberg et al. (1990). However, the patchiness of the HNF-biomass observed in our study was high due to the occasional occurrence of large choanoflagellates $(>3 \mu \mathrm{m})$. This may have masked any diel signal in the distribution pattern.

The majority of field studies have investigated horizontal patchiness along transects without considering the temporal variation a station. In that way, important information is lost about fine-scale variation and complicates the transfer of variance from shorter to longer timescales (Marine Zooplankton Colloquium 1 1989). Thus, the fine-scale temporal variability as observed 

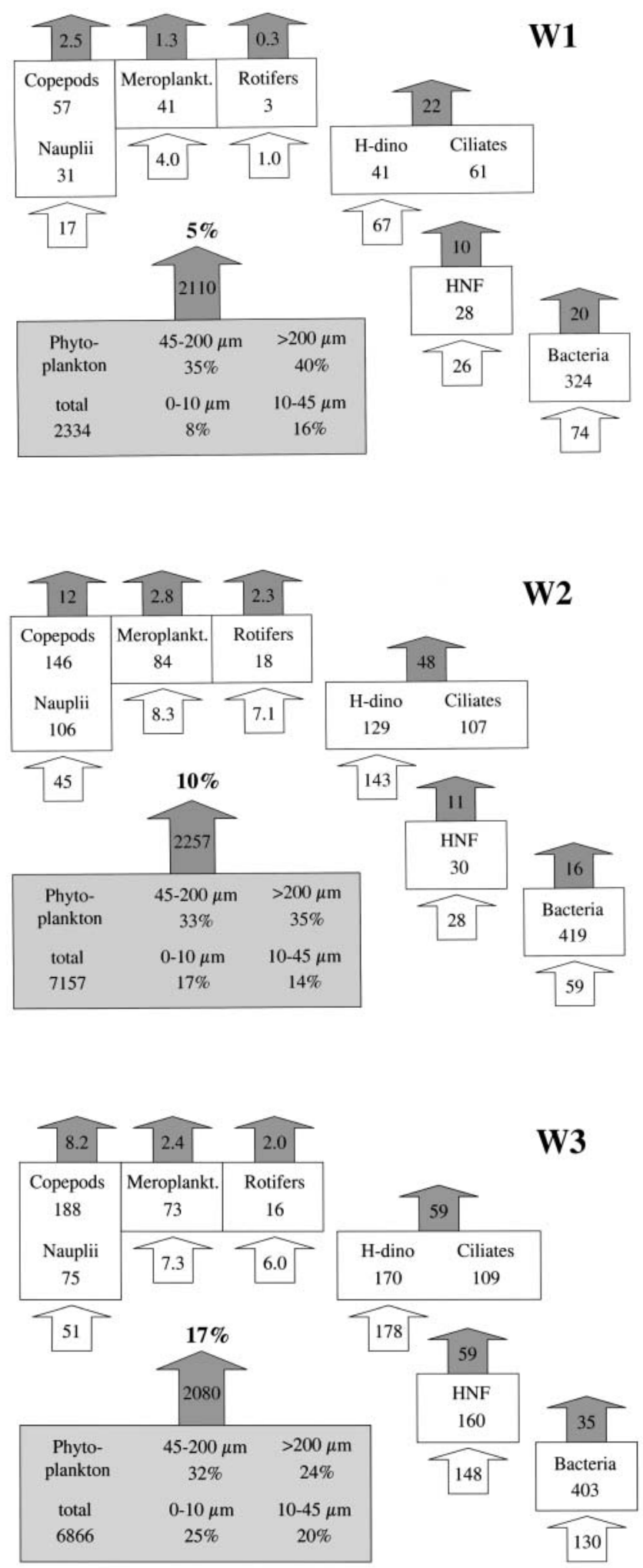

Fig. 9. Carbon budgets for W1, W2 and W3. Boxes are biomass $\left(\mathrm{mg} \mathrm{C} \mathrm{m}^{-2}\right)$ and black and white arrows are carbon production and carbon ingestion $\left(\mathrm{mgC} \mathrm{m}^{-2} \mathrm{~d}^{-1}\right)$, respectively. The potential grazing impact $(\%)$ by all the zooplankton groups on primary production is indicated in bold here is important to consider as it has implications for sampling, understanding and modeling of pelagic ecosystems.

\section{Carbon flux and the classical food chain}

Simultaneous measurements on the mesozooplankton and the microbial part of the food web during a spring bloom are scarce. The present investigation documents that the biomass of bacteria and heterotrophic protists can be comparable to that of the mesozooplankton. To illustrate the fate of the pelagic production during our study, we have established carbon flux budgets for the 3 identified water masses taking into account the observed temporal variability in rates and distributions (Fig. 9).

The total potential primary productivity occurring was high with an average of $2150 \mathrm{mgC} \mathrm{m}^{-2} \mathrm{~d}^{-1}$ in all water masses. This is in agreement with earlier studies in the Skagerrak (Heilmann et al. 1994) and in the adjacent areas (Kattegat: Richardson \& Christoffersen 1991, North Sea: Nielsen \& Richardson 1989) made under spring bloom conditions. The specific potential growth rate of phytoplankton was, however, much higher in W1 than in W2 and W3. This, together with the low chl a concentration and high nutrient levels in $\mathrm{W} 1$, indicates that W1 represents an early stage of the spring bloom. The 'Skagerrak water' W3 was sampled again $4 \mathrm{~d}$ after encountering W1. On the later sampling date, the chl a concentrations were higher and the nutrient levels lower. The decrease in surface nitrate concentration $(7.2 \mu \mathrm{M})$ between the 2 sampling occasions corresponded to the predicted nitrate utilization (assuming $\mathrm{C}: \mathrm{N}=6.6$ ) by primary production (5.4 to $6.7 \mu \mathrm{M}, 4$ to $5 \mathrm{~d})$.

Baltic water outflow (W2) was investigated in between the 2 sampling periods of Skagerrak water. W2 had as high chl a concentrations as W3 but higher nutrient levels. In addition, the relative abundance of phytoplankton cells $>45 \mu \mathrm{m}$ declined from W1 to W2 and, finally, to W3, indicating different stages of phytoplankton succession in the water masses. We, therefore, assume that the 3 water masses represent 3 different stages of the spring bloom. The phytoplankton community as a whole, however, never seemed to be nutrient-depleted, as the 480/665 absorbance ratio remained well below the critical value of 2.0 (Heath et al. 1990) throughout the study. Light was, instead, believed to be the limiting factor, and the specific growth rates in W2 and W3 were probably reduced due to low irradiance and self-shading at the high biomass levels present.

The classical food chain did not dominate early transfer in the pelagic food web during the spring 
bloom period in the Skagerrak, in contrast to what Tiselius (1988) suggested and what was observed in the adjacent deep part of the North Sea (Williams \& Lindley 1980, Fransz et al. 1991). In fact, the copepods ingested less than $3 \%$ of the daily primary production despite the presence of an overwintering copepod population in these waters. The observed copepod biomass was quite low ( 57 to $188 \mathrm{mg} \mathrm{C} \mathrm{m}^{-2}$ ) compared to May-values of 375 to $920 \mathrm{mgC} \mathrm{m}^{-2}$ (recalculated from Rosenberg et al. 1990) observed in the same region. Calanus finmarchicus overwinters in the deep coastal basins of Skagerrak, and spawning mainly takes place in March (Jonasdottir et al. 1999). However, the recruitment success depends not only on the in situ population but also on the imported stock from the northern North Sea (Heath et al. 1999). Here, overwintering C. finmarchicus has been observed in the surface layer from late March (Williams \& Lindley 1980, Niehoff et al. 1999) ready to exploit the spring bloom in April to May efficiently.

In the Skagerrak, the water column is stratified most of the year due to the influence of brackish water from the Baltic Sea. Consequently, the spring bloom starts in early March before the copepod population is well established. In the southern and shallower regions of the North Sea, the spring bloom can also begin early in February-March (Nielsen \& Richardson 1989). Here, less than $2 \%$ of daily primary production has been observed to be grazed by mesozooplankton due to a low copepod biomass (Nielsen \& Richardson 1989). In the Kattegat, copepods grazed between 2 to $20 \%$ of daily primary production during the bloom in March (Kiørboe \& Nielsen 1994). Thus, the classical food chain in the Skagerrak resembles shallow areas such as the Kattegat and Southern North Sea, possibly due to its year-round stratification.

The Calanus finmarchicus SEP rate in Skagerrak water (W1 and W3) was considerably lower than earlier observations during bloom conditions at similar temperatures (Diel \& Tande 1992, Niehoff et al. 1999, Madsen et al. 2001). Actually, the measured SEP rate $\left(2.4 \% \mathrm{~d}^{-1}\right.$ or 11 eggs female $\left.{ }^{-1} \mathrm{~d}^{-1}\right)$ in the Skagerrak water was comparable to those observed during prebloom conditions (Niehoff et al. 1999, Richardson et al. 1999). However, the response time of SEP rate by C. finmarchicus to higher food concentrations can be up to 8 to $15 \mathrm{~d}$ after a period of starvation (Marshall \& Orr 1955, Runge \& Plourde 1996). The development time of the bloom from W1 to W3 was $4 \mathrm{~d}$, and we therefore suggest that the observed low SEP rate was caused by a lag period. In contrast, the SEP rate in W2 was as high as for bloom conditions $\left(4.4 \% \mathrm{~d}^{-1}\right.$ or 20 eggs female ${ }^{-1} \mathrm{~d}^{-1}$ ). Thus, it seems likely that the bloom in W2 was initiated earlier than in the Skager- rak water and that the SEP rate by $C$. finmarchicus therefore was adjusted to the elevated food concentrations.

The often ignored groups, meroplankton and rotifers, contributed significantly to the mesozooplankton biomass. Small polychaete larvae $(200 \mu \mathrm{m})$ dominated the meroplankton biomass, and therefore we used the growth rate of Mediomastus fragile (polychaeta) (Hansen 1993) to estimate the grazing impact. However, this specific growth rate was quite low $\left(3.3 \% \mathrm{~d}^{-1}\right)$ and resulted in a low grazing impact on the primary production $(<0.3 \%)$. Rotifers, on the other hand, had a relatively lower biomass compared to the meroplankton but a high growth rate (Hansen et al. 1997a). This resulted in their grazing impact being the same order of magnitude as that of meroplankton.

In summary, the grazing impact by the mesozooplankton community on the spring phytoplankton bloom was, in general, very low $(<4 \%)$. We assume, however, that the importance of the classical food chain will increase as the copepod population builds up in response to the bloom and the primary production decreases to 'non-bloom' levels. This was documented by Tiselius (1988), who found that up to $48 \%$ of the primary production was grazed by copepods in May, when Calanus finmarchicus was dominant in the Skagerrak.

\section{Microbial food web}

During the Skagerrak spring bloom, a well-established bacterial community was observed, and it contributed with the largest pool of heterotrophic biomass. Additionally, the bacterial community consumed 1.3 to 4.4 times more of the potential primary production than the copepods. Bacterial production was, on the other hand, relatively low compared to primary production (3 to $7 \%$ ). In the southern North Sea and the Baltic Sea, the bacterial production peak lagged $2 \mathrm{wk}$ behind the culmination of the spring bloom (Lancelot \& Billen 1984, Lignell et al. 1993). This is supported by observations at similar temperatures in the Disko Bay, where the relative importance of bacterial production to primary production was low (1 to $5 \%$ ) during the spring bloom (Nielsen \& Hansen 1995). After the spring bloom, however, the relative importance of bacteria will presumably increase as observed by Nielsen \& Hansen (1995).

Despite significant variations in phytoplankton biomass between water masses, no correlation between primary and bacterial production was observed. However, a positive correlation between bacterial production and Calanus-ingestion was observed. Exponentially growing phytoplankton cells are believed to leak 
around $5 \%$ of primary production as DOM (Nagata 2000). This would imply a leakage of 104 to $113 \mathrm{mgC}$ $\mathrm{m}^{-2} \mathrm{~d}^{-1}$, a value that is roughly similar to the carbon demand of the bacteria (59 to $130 \mathrm{mg} \mathrm{C} \mathrm{m}^{-2} \mathrm{~d}^{-1}$ ). However, the DOM released by phytoplankton might not have the same nutritional quality compared to breakage of cells during copepod feeding. DOM generated by sloppy feeding corresponds to 43 to $135 \mathrm{mg} \mathrm{C} \mathrm{m}^{-2}$ $\mathrm{d}^{-1}$ assuming that $54 \%$ of the grazed carbon is lost when feeding on large diatoms (Møller \& Nielsen 2001). Leaking of non-absorbed organic material from fecal pellets can also be important at high food concentrations (Jumars et al. 1989). Thus, it might be possible that, even during intense blooms, the bacterial production is fueled by high-quality substrate supplied by zooplankton grazing activity. Bacterial biomass was, nevertheless, relatively constant at all stations, presumably because the HNF-grazing on bacteria balanced the production (Andersen \& Fenchel 1985). The calculated carbon demand by the HNF was, on the other hand, somewhat higher than the bacterial ingestion assessed by FLB-experiments, so small phytoplankton cells also contributed to the diet.

The high biomass and fast growth rates of the protozooplankton compared to the copepods resulted in a grazing impact that exceeded that of mesozooplankton by a factor of 2 to 4 . Heterotrophic dinoflagellates are known to ingest diatom chains (Hansen 1992) while ciliates, on the other hand, rely on nanophytoplankton and small diatoms (Pierce \& Turner 1992). Thus, the larger protozoans compete with the copepods for diatom-prey and increase the direct grazing impact on the phytoplankton.

There are only a few studies from deeper waters hosting an overwintering copepod population, where the grazing by the protozooplankton has been assessed during the spring bloom. In Puget Sound and the Gulf of Alaska (Washington), protozooplankton grazing was most important when the phytoplankton biomass was high $\left(>2 \mathrm{\mu g} \mathrm{l}^{-1}\right)$ and consisted of large cells (Strom et al. 2001). Here the protozooplankton could graze $78 \%$ of the daily primary production. However, grazing by Calanus sp. and other predators was not measured in that study. Those workers concluded that other loss rates such as grazing, sedimentation or advection must have been relatively insignificant during the study period. During the spring bloom in 3 Norwegian fjords, the grazing impact by the protozooplankton was 12 to $26 \%$ of daily primary production in the upper $20 \mathrm{~m}$ (Archer et al. 2000). In Disko Bay (Greenland), the grazing impact by protozooplankton during the diatom bloom was 3 times higher than that of copepods (Nielsen \& Hansen 1995). Thus, grazing by protozooplankton appears to be important during blooms of large diatom cells in a variety of habitats.
The heterotrophic dinoflagellates and ciliates could easily meet their carbon demand directly from the phytoplankton.

Heterotrophic protists are, on the other hand, a potential food source for copepods (Stoecker \& Capuzzo 1990, Kleppel 1993). Predation on protozooplankton is, however, often relaxed during net phytoplankton bloom, and this allows the protozooplankton to peak along with the phytoplankton (Nielsen \& Kiørboe 1994). During a spring bloom in the Norwegian Sea, the specific ingestion rate on ciliates by Calanus finmarchicus was $1.8 \%$ of body-C $\mathrm{d}^{-1}$ and only constituted $6 \%$ of the phytoplankton ingestion (Irigoien et al. 1998). In the present investigation, this would give an ingestion rate corresponding to 5 to $6 \%$ of daily ciliate and heterotrophic dinoflagellate production in the 3 water masses if the specific ingestion rate was applied for all copepods. For C. finmarchicus, the ingestion of protozooplankton, then, corresponded to 7 to $10 \%$ of the phytoplankton ingestion. Following the spring bloom, however, the accumulated protozooplankton biomass is, then, an important additional food source for the copepods. Thus, a key role of the protozooplankton during net phytoplankton blooms is to conserve energy in the euphotic zone that can be utilized by other trophic levels during the period following the spring bloom.

In conclusion, protozooplankton were the most important grazers during the spring bloom in this study. Despite the presence of an overwintering Calanus population, the meso- and protozooplankton community together grazed less than $17 \%$ of daily primary production. Thus, in this case, the majority of the produced phytoplankton biomass will eventually form large, fast-sinking aggregates and leave the euphotic zone ungrazed as a potential food source for the benthos (Smetacek 1985, Kiørboe et al. 1994).

Acknowledgements. This study was supported by the KEYCOP-grant (MAST III: MAS3-CT97-0148) and the Danish National Research Council grant no. 9801391. We are grateful for the technical assistance of Birgit Søborg, Kajsa Tönnesson, Peter Tiselius and the crew of 'Dana'. We would like to thank 3 anonymous revierwers for editorial suggestions on an earlier version of this manuscript.

\section{LITERATURE CITED}

Andersen P, Fenchel T (1985) Bacterivory by microheterotrophic flagellates in seawater samples. Limnol Oceanogr 30:198-202

Angel MV (1992) Long-term, large-scale patterns in marine pelagic systems. In: Giller PS, Hildrew AG, Raffaelli DG (eds) Aquatic Ecology: scale, pattern and process. Blackwell Science, Oxford, p 403-439

Archer SD, Verity PG, Stefels J (2000) Impact of microzooplankton on the progression and fate of the spring 
bloom in fjords of northern Norway. Aquat Microb Ecol $22: 27-41$

Båmstedt U, Gifford DJ, Irigoien X, Atkinson A, Roman M (2000) Feeding. In: Harris R, Wiebe P, Lenz J, Skjoldal HR, Huntley M (eds) ICES zooplankton methodology manual. Academic Press, London, p 297-399

Banse K (1964) On the vertical distribution of zooplankton in the sea. Prog Oceanogr 2:53-125

Berggreen U, Hansen B, Kiørboe T (1988) Food size spectra, ingestion and growth of the copepod Acartia tonsa during development: implications for determination of copepod production. Mar Biol 99:341-352

Caron DA, Dam HG, Kremer P, Lessard EJ and 6 others (1995) The contribution of microorganisms to particulate carbon and nitrogen in surface waters of the Sargasso Sea near Bermuda. Deep-Sea Res I 42:943-972

Christaki U, Gaudy R, Kerambrun P (1998) A study of the effects of migratory zooplankton on microbial populations in surface waters of the NW Mediterranean. J Exp Mar Biol Ecol 225:173-183

Deason EE (1980) Grazing of Acartia hudsonica (A. clausi) on Skeletonema costatum in Narragansett Bay (USA): influence of food concentration and temperature. Mar Biol 60: $101-113$

Diel S, Tande K (1992) Does the spawning of Calanus finmarchicus in high-latitudes follow a reproducible pattern. Mar Biol 113:21-31

Folt CL, Burns CW (1999) Biological drivers of zooplankton patchiness. Trends Ecol Evol 14:300-305

Fotel FL, Jensen NJ, Wittrup L, Hansen BW (1999) In situ and laboratory growth by a population of blue mussel larvae (Mytilus edulis L.) from a Danish embayment, Knebel Vig. J Exp Mar Biol Ecol 233:213-230

Fransz HG, Colebrook JM, Gamble JC, Krause M (1991) The zooplankton of the North Sea. Neth J Sea Res 28:1-52

Fuhrman JA, Azam F (1980) Bacterioplankton secondary production estimates for coastal waters of British Columbia, Antarctica, and California. Appl Environ Microbiol 39: 1085-1095

Fuhrman JA, Eppley RW, Hagstöm Å, Azam F (1985) Diel variations in bacterioplankton, phytoplankton, and related parameters in the Southern California Bight. Mar Ecol Prog Ser 27:9-20

Gallager SM, Davis CS, Epstein AW, Solow A, Beardsley RC (1996) High-resolution observations of plankton spatial distributions correlated with hydrography in the Great South Channel, Georges Bank. Deep-Sea Res I 43: 1627-1663

Giorgio PA, Cole JJ (2000) Bacterial energetics and growth efficiency. In: Kirchman DL (ed) Microbial ecology of the oceans. Wiley-Liss, New York, p 289-325

Gowen RJ, Raine R, Dickey-Collas M, White M (1998) Plankton distributions in relation to physical oceanographic features on the southern Malin Shelf, August 1996. ICES J Mar Sci 55:1095-1111

Grasshoff K (1976) Methods of seawater analysis. Verlag Chemie, Weinheim

Haney JF (1988) Diel patterns of zooplankton behavior. Bull Mar Sci 43:583-603

Hansen PJ (1991) Quantitative importance and trophic role of heterotrophic dinoflagellates in a coastal pelagial food web. Mar Ecol Prog Ser 73:253-262

Hansen PJ (1992) Prey size selection, feeding rates and growth dynamics of heterotrophic dinoflagellates with special emphasis on Gyrodinium spirale. Mar Biol 114: 327-334

Hansen B (1993) Aspects of feeding, growth and stage devel- opment by trochophora larvae of the boreal polychaete Mediomastus fragile (Rasmussen) (Capitellidae). J Exp Mar Biol Ecol 166:273-288

Hansen B, Ockelmann KW (1991) Feeding behavior in larvae of the opisthobranch Philine aperta. I. Growth and functional response at different developmental stages. Mar Biol 111:255-261

Hansen B, Wernberg Moller T, Wittrup L (1997a) Particle grazing efficiency and specific growth efficiency of the rotifer Brachionus plicatilis (Müller). J Exp Mar Biol Ecol 215:217-233

Hansen PJ, Bjørnsen PK, Hansen BW (1997b) Zooplankton grazing and growth: scaling within the $2-2,000-\mu \mathrm{m}$ body size range. Limnol Oceanogr 42:687-704

Hay SJ, Kiørboe T, Matthews A (1991) Zooplankton biomass and production in the North Sea during the autumn circulation experiment, October 1987-March 1988. Cont Shelf Res 11:1453-1476

Heath MR, Richardson K, Kiørboe T (1990) Optical assessment of phytoplankton nutrient depletion. J Plankton Res 12:381-396

Heath MR, Backhaus JO, Richardson K, McKenzie E and 11 others (1999) Climate fluctuations and the spring invasion of the North Sea by Calanus finmarchicus. Fish Oceanogr 8:163-176

Heilmann JP, Richardson K, Ærtebjerg G (1994) Annual distribution and activity of phytoplankton in the Skagerrak/ Kattegat frontal region. Mar Ecol Prog Ser 112:213-223

Hirche HJ, Mumm N (1992) Distribution of dominant copepods in the Nansen basin, Arctic Ocean, in summer. DeepSea Res 39 (Suppl):S485-S505

Hobbie JE, Daley RJ, Jasper S (1977) Use of nucleopore fillers for counting bacteria by fluorescence microscopy. Appl Environ Microbiol 33:1225-1228

Irigoien X, Head R, Klenke U, Meyer-Harms B, Harbour D, Niehoff B, Hirche HJ, Harris R (1998) A high frequency time series at Weathership M, Norwegian Sea, during the 1997 spring bloom: feeding of adult female Calanus finmarchicus. Mar Ecol Prog Ser 172:127-137

Joiris C, Billen G, Lancelot C, Daro MH and 5 others (1982) A budget of carbon cycling in the belgian coastal zone: relative roles of zooplankton, bacterioplankton and benthos in the utilization of primary production. Neth J Sea Res 16: $260-275$

Jonasdottir SH, Hay SJ, Heath MR, Madden H, Richardson K (1999) Spring invasion of the northern North Sea by Calanus finmarchicus. Abstract presented at ICES Symposium on the population dynamics of Calanus in the North Atlantic, http://Calanus.nfh.uit.no

Jumars PA, Penry DL, Baross JA, Perry MJ, Frost BW (1989) Closing the microbial loop: dissolved carbon pathway to heterotrophic bacteria from incomplete ingestion, digestion and absorption in animals. Deep-Sea Res I 36: 483-496

Kiørboe T (1993) Turbulence, phytoplankton cell-size, and the structure of pelagic food webs. Adv Mar Biol 29:1-72

Kiørboe T, Nielsen TG (1994) Regulation of zooplankton biomass and production in a temperate, coastal ecosystem: 1. Copepods. Limnol Oceanogr 39:493-507

Kiørboe T, Møhlenberg F, Riisgård HU (1985) In situ feeding rates of planktonic copepods: A comparison of four methods. J Exp Mar Biol Ecol 88:67-81

Kiørboe T, Kaas H, Kruse B, Møhlenberg F, Tiselius PT, Ærtebjerg G (1990) The structure of the pelagic food web in relation to water column structure in the Skagerrak. Mar Ecol Prog Ser 59:19-32

Kiørboe T, Lundsgaard C, Olesen M, Hansen JLS (1994) 
Aggregation and sedimentation processes during a spring phytoplankton bloom: a field experiment to test coagulation theory. J Mar Res 52:297-323

Kiørboe T, Saiz E, Viitasalo M (1996) Prey switching behaviour in the planktonic copepod Acartia tonsa. Mar Ecol Prog Ser 143:65-75

Klein Breteler WCM, Fransz HG, Gonzalez SR (1982) Growth and development of four calanoid copepod species under experimental and natural conditions. Neth J Sea Res 16: 195-207

Kleppel GS (1993) On the diets of calanoid copepods. Mar Ecol Prog Ser 99:183-195

Lancelot C, Billen G (1984) Activity of heterotrophic bacteria and its coupling to primary production during the spring phytoplankton bloom in the southern bight of the North Sea. Limnol Oceanogr 29:721-730

Lee S, Fuhrman JA (1987) Relationships between biovolume and biomass of naturally derived marine bacterioplankton. Appl Environ Microbiol 53:1298-1303

Levinsen H, Nielsen TG, Hansen BW (1999) Plankton community structure and carbon cycling on the western coast of Greenland during the stratified summer situation. II. Heterotrophic dinoflagellates and ciliates. Aquat Microb Ecol 16:217-232

Lignell R, Heiskanen AS, Kuosa H, Gundersen K, Kuuppoleinikki P, Pajniemi R, Uitto A (1993) Fate of a phytoplankton spring bloom - sedimentation and carbon flow in the planktonic food web in the northern Baltic Sea. Mar Ecol Prog Ser 94:239-252

Madsen SD, Nielsen TG, Hansen BW (2001) Annual population development and production by Calanus finmarchicus, C-glacialis and C-hyperboreus in Disko Bay, western Greenland. Mar Biol 139:75-93

Marine Zooplankton Colloquium 1 (1989) Future marine zooplankton research-a perspective. Mar Ecol Prog Ser 55: 197-206

Marshall SM, Orr AP (1955) The biology of a marine copepod Calanus finmarchicus (Gunnerus). Oliver and Boyd, London

Menden-Deuer S, Lessard EJ (2000) Carbon to volume relationships for dinoflagellates, diatoms, and other protist plankton. Limnol Oceanogr 45:569-579

Metaxas A (2001) Behaviour in flow: perspectives on the distribution and dispersion of meroplanktonic larvae in the water column. Can J Fish Aquat Sci 58:86-98

Møller EF, Nielsen TG (2001) Production of bacterial substrate by marine copepods: effect of phytoplankton biomass and cell size. J Plankton Res 23:527-536

Nagata T (2000) Production mechanisms of dissolved organic matter. In: Kirchman DL (ed) Microbial ecology of the oceans. Wiley-Liss, New York, p 121-152

Niehoff B, Klenke U, Hirche HJ, Irigoien X, Head R, Harris R (1999) A high frequency time series at Weathership $M$, Norwegian Sea, during the 1997 spring bloom: the reproductive biology of Calanus finmarchicus. Mar Ecol Prog Ser 176:81-92

Nielsen TG, Hansen B (1995) Plankton community structure and carbon cycling on the western coast of Greenland during and after the sedimentation of a diatom bloom. Mar Ecol Prog Ser 125:239-257

Nielsen TG, Hansen PJ (1999) Dyreplankton i danske farvande. Tema-rapport fra DMU, Miljø- og Energiministeriet, Copenhagen

Nielsen TG, Kiørboe T (1994) Regulation of zooplankton biomass and production in a temperate, coastal ecosystem. 2. Ciliates. Limnol Oceanogr 39:508-519

Nielsen TG, Richardson K (1989) Food chain structure of the
North Sea plankton communities: seasonal variations of the role of the microbial loop. Mar Ecol Prog Ser 56:75-88

Nielsen TG, Sabatini M (1996) Role of cyclopoid copepods Oithona spp. in North Sea plankton communities. Mar Ecol Prog Ser 139:79-93

Nielsen TG, Møller EF, Satapoomin S, Ringuette M, Hopcroft RR (2002) Egg hatching rate of the cyclopoid Oithona similis in Arctic, temperate and tropical waters. Mar Ecol Prog Ser 236:301-306

Olesen M, Lundsgaard C (1995) Seasonal sedimentation of autochthonous material from the euphotic zone of a coastal system. Estuar Coast Shelf Sci 41:475-490

Pierce RW, Turner JT (1992) Ecology of planktonic ciliates in marine food webs. Rev Aquat Sci 6:139-181

Pinel-Alloul B (1995) Spatial heterogenity as a multiscale characteristic of zooplankton community. Hydrobiologia 300/301:17-42

Porter KG, Feig YS (1980) The use of DAPI for identifying and counting aquatic microflora. Limnol Oceanogr 25:943-948

Richardson K, Christoffersen A (1991) Seasonal distribution and production of phytoplankton in the southern Kattegat. Mar Ecol Prog Ser 78:217-227

Richardson K, Nielsen TG, Pedersen FB, Heilmann JP, Lokkegaard B, Kaas H (1998) Spatial heterogeneity in the structure of the planktonic food web in the North Sea. Mar Ecol Prog Ser 168:197-211

Richardson K, Jonasdottir SH, Hay SJ, Christoffersen A (1999) Calanus finmarchicus egg production and food availability in the Faroe-Shetland Channel and northern North Sea: October-March. Fish Oceanogr 8(Suppl 1): 153-162

Riemann B, Bjørnsen PK, Newell S, Fallon R (1987) Calculation of cell production of coastal marine bacteria based on measured incorporation of $\left[{ }^{3} \mathrm{H}\right]$ thymidine. Limnol Oceanogr 32:471-476

Rosenberg R, Dahl E, Edler L, Fyrberg L and 10 others (1990) Pelagic nutrient and energy transfer during spring in the open and coastal Skagerrak. Mar Ecol Prog Ser 61: 215-231

Runge JA, Plourde S (1996) Fecundity characteristics of Calanus finmarchicus in coastal waters of Eastern Canada. Ophelia 44:171-187

Sabatini M, Kiørboe T (1994) Egg production, growth and development of the cyclopoid copepod Oithona similis. J Plankton Res 16:1329-1351

Salat J, Marrasé C (1994) Exponential and linear estimations of grazing on bacteria-effects of changes in the proportion of marked cells. Mar Ecol Prog Ser 104(1-2):205-209

Satapoomin S (1999) Carbon content of some common tropical Andaman Sea copepods. J Plankton Res 21:2117-2123

Simon M (1994) Diel variability of bacterioplankton biomass production and cell multiplication in Lake Constance. Arch Hydrobiol 130:283-302

Smetacek VS (1981) The annual cycle of protozooplankton in the Kiel Bight. Mar Biol 63:1-11

Smetacek VS (1985) Role of sinking in diatom life-history cycles: ecological, evolutionary and geological significance. Mar Biol 84:239-251

Smith SL, Lane PVZ (1988) Grazing of the spring diatom bloom in the New York Bight by the calanoid copepods Calanus finmarchicus, Metridia lucens and Centropages typicus. Cont Shelf Res 8:485-509

Sorokin YuI, Kopylov AI, Mamaeva NV (1985) Abundanced and dynamics of microplankton in the central tropical Indian Ocean. Mar Ecol Prog Ser 24:27-41

Steele JH (1974) The structure of marine ecosystems. Blackwell Scientific Publications, Oxford, p 1-127 
Stoecker DK, Capuzzo JM (1990) Predation on protozoa: its importance to zooplankton. J Plankton Res 12:891-908

Strickland JD, Parsons TR (1972) A practical handbook of seawater analysis. Bull Fish Res Bd Can 167

Strom SL, Benner R, Ziegler S, Dagg MJ (1997) Planktonic grazers are a potentially important source of marine dissolved organic carbon. Limnol Oceanogr 42:1364-1374

Strom SL, Brainard MA, Holmes JL, Olson MB (2001) Phytoplankton blooms are strongly impacted by microzooplankton grazing in coastal North Pacific waters. Mar Biol 138: $355-368$

Svansson A (1975) Physical and chemical oceanography of the Skagerrak and the Kattegat. I. Open sea conditions. Report 1, Fish Bd Sweden, Inst Mar Res (GENERIC), Lysekil, p 2-57

Talpsepp L, Kûnnis K, Pavelson J, Piirso K, Porgasaar V, Poder T (1999) Hydrophysical variability in the central and eastern Skagerrak during SKAGEX-90 and its reflection in biological parameters. ICES J Mar Sci 56 (Suppl): $72-83$

Tiselius P (1988) Effects of diurnal feeding rhythms, species compositions and vertical migration on the grazing impact of calanoid copepods in the Skagerrak and Kattegat. Ophelia 28:215-230

Tiselius P, Nielsen TG, Breul G, Jaanus A, Korschenko A, Witek Z (1991) Copepod egg production in the Skagerrak during SKAGEX, May-June 1990. Mar Biol 111: 445-453

Torreton JP, Bouvy M, Arfir R (1994) Diel fluctuations of bac-

Editorial responsibility: Otto Kinne (Editor),

Oldendorf/Luhe, Germany terial abundance and productivity in a shallow eutrophic tropical lagoon. Arch Hydrobiol 131:79-92

Utermöhl H (1958) Zur Vervollkommnung der quantitativen Phytoplankton-Methodik. Mit Int Verein Theor Limnol 9, 1-38

Vasquez-Dominguez E, Peters F, Gasol JM, Vaque D (1999) Measuring the grazing losses of picoplankton: methodological improvements in the use of fluorescently labeled tracers combined with flow cytometry. Aquat Microb Ecol 20(2):119-128

Verity PG, Robertson CY, Tronzo CR, Andrews MG, Nelson JR, Sieracki ME (1992) Relationships between cell volume and nitrogen content of marine photosynthetic nanoplankton. Limnol Oceanogr 37:1434-1446

Visser AW, Saito H, Saiz E, Kiørboe T (2001) Observations of copepod feeding and vertical distribution under natural turbulent conditions in the North Sea. Mar Biol 138: 1011-1019

Wassmann P (1998) Retention versus export food chains: processes controlling sinking loss from marine pelagic systems. Hydrobiologia 363:29-57

Wiafe G, Frid CJ (1996) Short-term temporal variation in coastal zooplankton communities: the relative importance of physical and biological mechanisms. J Plankton Res 18: $1485-1501$

Williams R, Lindley JA (1980) Plankton of the Fladen Ground during FLEX 76. III. Vertical distribution, population dynamics and production of Calanus finmarchicus (Crustacea; Copepoda). Mar Biol 60:47-56

Submitted: August 8, 1999; Accepted: February 15, 2001 Proofs received from author(s): August 6, 2002 